\title{
A Review on the Effect of Soil Compaction and its Management for Sustainable Crop Production
}

\author{
Md Rayhan Shaheb ${ }^{1,2}$ (D) $\cdot$ Ramarao Venkatesh $^{3}$ (D) Scott A. Shearer ${ }^{1}$ (D)
}

Received: 25 April 2021 / Revised: 25 August 2021 / Accepted: 12 October 2021 / Published online: 24 November 2021

(c) The Author(s) 2021

\begin{abstract}
Purpose Sustainable crop production could contribute to feed and fuel for the ever-increasing global population. The use of heavy agricultural machinery has improved the efficiency of farming operations and increased global food production since the 1950s. But their negative impact on soil includes changing soil structure resulting in deteriorating soil productivity and environmental quality is being noticed for several decades. The purpose of this review is to summarize and help to better understand the effect of heavy machinery, tire inflation pressure, and field traffic on soil properties and crop development, yield, and economics of different farming systems published in the last 20 years.

Methods Search engines such as Google Scholar, Scopus, Science Direct, Springer Link, Wiley Online, Taylor \& Francis Online, Academia, and Research Gate platforms were used to collect and review the articles. This review includes indexed journals, conference and symposium proceedings, reports, academic presentations, and thesis/dissertations.

Results Soil compaction increases bulk density and soil strength and reduces soil porosity and soil hydraulic properties. Stunted plant root growth due to compaction of soil affects crop growth and development, and yield. Soil compaction resulting from heavy machinery traffic caused a significant crop yield reduction of as much as $50 \%$ or even more, depending upon the magnitude and the severity of compaction of the soil.

Conclusions High gross weight vehicles/machinery traffic damages soil structure and soil environment that are critical for sustainable crop production. The use of heavy machinery such as subsoiling for removing soil compaction results in more fuel use, increased use of energy, cost, and sometimes risks of re-compaction, further deteriorating soil conditions and causing additional adverse environmental consequences. The economics of different farming systems affected by soil compaction, potential soil compaction management strategies, and future research needs have also been discussed.
\end{abstract}

Keywords Field traffic $\cdot$ Heavy machinery $\cdot$ Soil compaction $\cdot$ Soil management $\cdot$ Sustainable agricultural production $\cdot$ Tire inflation pressure

Md Rayhan Shaheb

rshaheb.edu@gmail.com; shaheb.1@osu.edu

Ramarao Venkatesh

venkatesh.1@osu.edu

Scott A. Shearer

shearer.95@osu.edu

1 Department of Food, Agricultural and Biological Engineering, The Ohio State University, 590 Woody Hayes Drive, Columbus, OH 43210, USA

2 On-Farm Research Division, Bangladesh Agricultural Research Institute, Sylhet 3100, Bangladesh

3 Department of Horticulture and Crop Science, The Ohio State University, 2021 Coffey Road, Columbus, OH 43210, USA

\begin{tabular}{ll}
\multicolumn{2}{l}{ Nomenclature } \\
BD & Bulk density \\
CTF & Controlled traffic farming \\
EC & Electrical conductivity \\
LTP & Low tire inflation pressure \\
LWP & Leaf water potential \\
NDVI & Normalized difference vegetation index \\
PG & Plant growth \\
PR & Penetrometer resistance \\
RG & Root growth \\
RTF & Random traffic farming \\
Soil MC & Soil moisture content \\
Soil OM & Soil organic matter \\
STP & Standard/high tire inflation pressure \\
SQIs & Soil quality indicators \\
X-ray CT & X-ray computed tomography
\end{tabular}




\section{Introduction}

The rapidly increasing global population is expected to reach 9.6 billion by 2050, which requires increased food production to meet the demand without overwhelming the available resources. Sustainable agricultural production, ensuring food and nutrition security, and minimizing environmental damage are significant challenges that the world is currently facing. The introduction and use of farm machinery have revolutionized modern agricultural production and contributed to increased productivity and sustainability. Despite the benefit of saving money, labor, and timeliness of operation (ECIFM, 2017), heavy farm machinery causes soil compaction that impacts soil structure and decreases crop root growth, overall crop growth and development, and yield (Horn \& Fleige, 2003; Chan et al., 2006; McKenzie, 2010). Farm machinery requires varying load demands to perform multiple field operations such as tillage, planting, spraying, and harvesting (Pitla et al., 2016). The increased gross weight of agricultural machinery contributes to the increase in wheel loads and enhances the risk of soil compaction (Chamen, 2015; Keller et al., 2019). The increase in the gross weight of the equipment and an increase in the number of passes play significant roles in enhancing soil compaction in many parts of the world (Horn et al., 2019; Keller et al., 2019). Several studies have shown that soil compaction affects (a) soil properties such as (i) changes soil structure, (ii) increases bulk density (BD), (iii) increases penetrometer resistance (PR), (iv) reduces soil aeration, (v) decreases water infiltration, and (vi) reduces hydraulic conductivity and (b) crop growth by (i) increasing mechanical impediment to root growth, (ii) hampering root architecture, and (iii) decreasing distribution and development of roots (Gan-mor \& Clark, 2001; Li et al., 2001; Hamza \& Anderson, 2005; Raper \& Kirby, 2006; Chan et al., 2006; Radford et al., 2007; Hula et al., 2009; Horn et al., 2019; Keller et al., 2019). A typical example of soil structural damage due to wheel traffic in the agricultural field is shown in Fig. 1. Besides the changes in soil structure, compaction reduces soil pore space and increases soil strength while decreasing root growth and root elongation rate, which results in reduced water and nutrient uptake by crops (Nawaz et al., 2013; Sadras et al., 2016; Colombi \& Keller, 2019). The adverse effects of compaction on soil conditions further result in a decrease in plant emergence, plant establishment, and plant height (Sidhu \& Duiker, 2006; Millington et al., 2016; Shaheb, 2020). In severe cases, soil compaction substantially impacts crop growth, development, yield, and farm income (Hakansson, 2005; Chan et al., 2006; Botta et al., 2010; Chamen, 2011; Godwin et al., 2017; Shaheb et al., 2018; Colombi \& Keller,

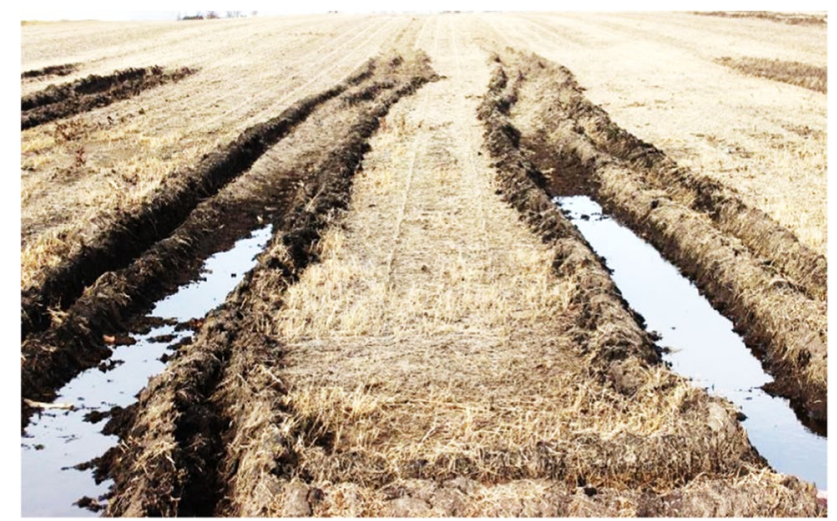

Fig. 1 Effect of soil compaction due to machinery traffic showing soil damage, increased waterlogging, and reduced water infiltration. Source: Al-Kaisi et al. (2018)

2019). Soil compaction at $150 \mathrm{~mm}$ depth caused primarily by heavy machinery increased soil BD $\left(1.93 \mathrm{Mg} \mathrm{m}^{-3}\right)$ and led to up to $38 \%$ yield loss in wheat (Ishaq et al., 2001a). The effects of compaction can significantly reduce crops yield by 10 to $15 \%$ (Godwin et al., 2019). The reduction in yield of corn due to compaction was reported to be as much as 50\% (Raghavan et al., 1979), 15 to $43 \%$ with $11-\mathrm{Mg}$ axle load followed by tillage (Voorhees, 2000), and $17 \%$ by the tillage two-wheel passes of $8-\mathrm{Mg}$ axle load and 300-kPa tire inflation pressure (Abu-Hamdeh, 2010).

Agricultural tires and tire inflation pressures have an impact on soil compaction. In general, topsoil compaction is caused by the ground contact pressure of a wheeled machine, while axle load is associated with the compaction in subsoil (Duiker, 2004a; Botta et al., 2008). Application of mechanical loads onto the soil via equipment fitted with pneumatic tires is the primary cause of compaction that damages the soil-water-air-plant systems (Misiewicz, 2010). Shaheb (2020) conducted a 3 -year compaction study in Drummer silty clay loam soil in Champaign county, Illinois. The study evaluated high flexion tires fitted on the tillage tractor $(10.3 \mathrm{Mg})$, planting tractor $(8.63 \mathrm{Mg})$, and combine harvester $(18.1 \mathrm{Mg})$ and operated at standard/high $(0.14-, 0.12-$, and $0.21 \mathrm{MPa})$ and low tire inflation pressures modes (0.07-, 0.05-, and 0.14 MPa, respectively). The results showed that standard/high inflation pressure tires (STP) caused a significant reduction in yield by $4.13 \%$ and $2.62 \%$ for corn in the second and third year, respectively, and $3.53 \%$ for soybean in the third year in comparison with the low inflation pressure tire system (LTP) (Shaheb, 2020). A brief overview of the effect of soil compaction due to heavy machinery, ground pressure, and field trafficking on soil and crop is presented in Fig. 2.

Strategies for reducing or alleviating soil compaction are focused mainly on subsoiling, control traffic farming (Antille et al., 2015; Chamen, 2015), suitable mechanization 


\section{Crop growth and development response: \\ - Decrease in growth \\ - Decrease in photosynthesis \\ - Decrease in total dry matter}

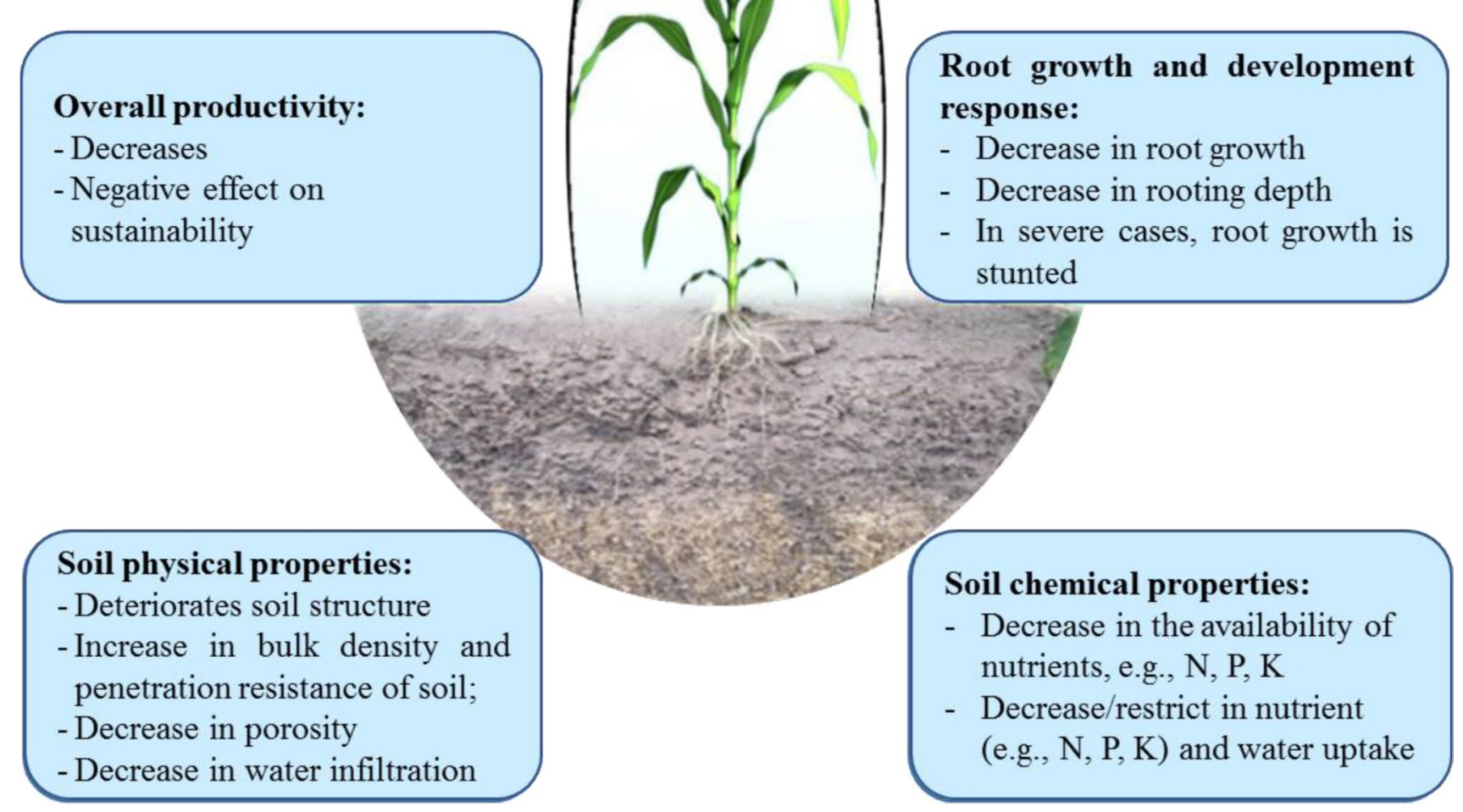

Fig. 2 A summary of the effect of soil compaction on soil properties and agricultural productivity (e.g., corn plant). Adapted from Shaheb et al. (2020)

practices (Godwin et al., 2015), low tire inflation pressure (Van Den Akker et al., 2003; Trautner \& Arvidsson, 2003; Smith et al., 2014a, 2014b; Godwin et al., 2017; Shaheb et al., 2018, 2020), conservation tillage (Raper \& Kirby, 2006), and incorporation of deep-rooted crops in rotation (Ishaq et al., 2001a, 2001b). Published modeling studies also help to understand, explain, and predict soil compaction (Defossez \& Richard, 2002; Schjønning et al., 2008; Berisso et al., 2013; Nawaz et al., 2013). However, there are scopes to emphasize soil compaction modeling works more on machine-soil-plant systems incorporating weather parameters. Subsoiling is often considered effective in removing soil compaction, but this operation sometimes causes a risk of re-compaction of soil (Ishaq et al., 2001a; Schwab et al., 2002; Busscher \& Bauer, 2003; Sidhu \& Duiker, 2006; Radford et al., 2007; Abu-Hamdeh, 2010; Botta et al., 2010). Nonetheless, deep subsoiling/tillage requires higher energy and fuel for soil treatment. So, the net on-farm cost of different soil compaction mitigation options is negative. Thus, avoiding soil compaction to be more cost-effective than alleviating, particularly true for subsoil compaction (Hallett et al., 2012). However, there is a need to summarize the published studies on the impact of soil compaction on agricultural productivity. The current review will provide detailed information on soil compaction and help better understand the effect of heavy machinery, tire pressure, and field trafficking on soil, crop growth and development, yield, and farm income based on the published literature from the last 20 years. This review (i) summarizes cause and effect of soil compaction on soil properties and crop development in different agroecosystems of the world; (ii) describes in detail how soil properties of diverse ecosystems change due to compaction; (iii) describes the impact of soil compaction in changing soil structure, pore space, water infiltration, soil 
hydraulic properties, soil air permeability, run-off, and soil erosion; (iv) delineates the possible management strategies of soil compaction; and, finally, (v) outlines future research required to address soil compaction for sustainable soil management and agricultural production.

\section{Methods}

The present review used 350 published articles from the last 20 years. The most relevant publications were collected using search engines such as Google Scholar, Scopus, Science Direct, Springer Link, Wiley Online, Taylor \& Francis Online, Academia, and Research Gate platforms. It includes indexed journals, conference and symposium proceedings, reports, academic presentations, and thesis/ dissertations. The focus here was to address compaction and related issues as a result of using heavy machinery, ground and tire pressures, and field traffic on soil conditions and its effect on agricultural production. Out of 350 articles, 193 articles were found more relevant to address these issues mentioned before and organized accordingly. Furthermore, efforts have been made to present currently available and possible strategies for alleviating soil compaction to effectively improve soil environment and ecosystems effectively and thus agricultural productivity and sustainability. A summary of the topics, search, and selection procedure used for the review is shown in Fig. 3.

\section{Soil Compaction}

Soil compaction reduces the volume of a given mass of soil, i.e., decrease in void ratio and porosity which results in an increases in BD of soil (Keller, 2004). It occurs when soils are subject to stresses that exceed their strength (Soehne, 1958). Stress in soils at the soil-tire interface is a function of tire inflation pressure, equipment load (wheel), tire properties, and soil conditions (Arvidsson \& Keller, 2007). The available report shows that approximately 68 million ha of land worldwide have issues due to soil compaction (Oldeman, 1992; Fig. 4), which could increase in the coming years. This implies that there is an urgent need to assess and determine the worldwide affected areas due to compaction,

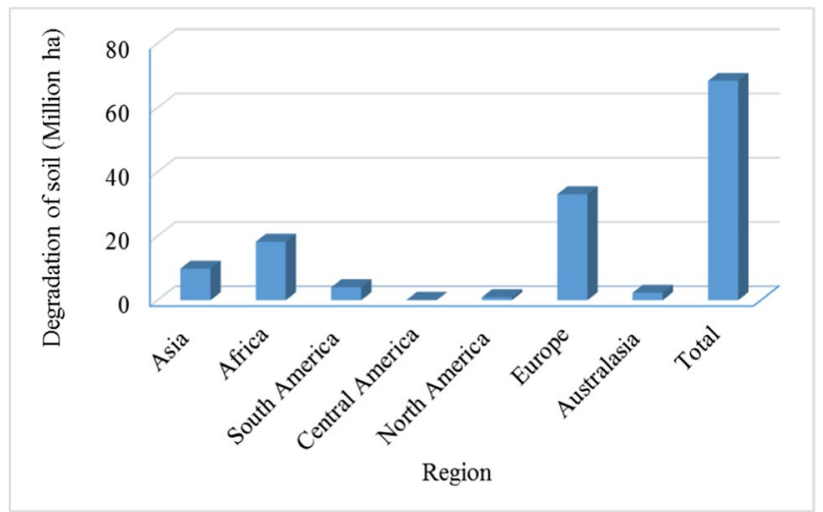

Fig. 4 Degradation of soil due to soil compaction in different continents. Adapted from Oldeman (1992)

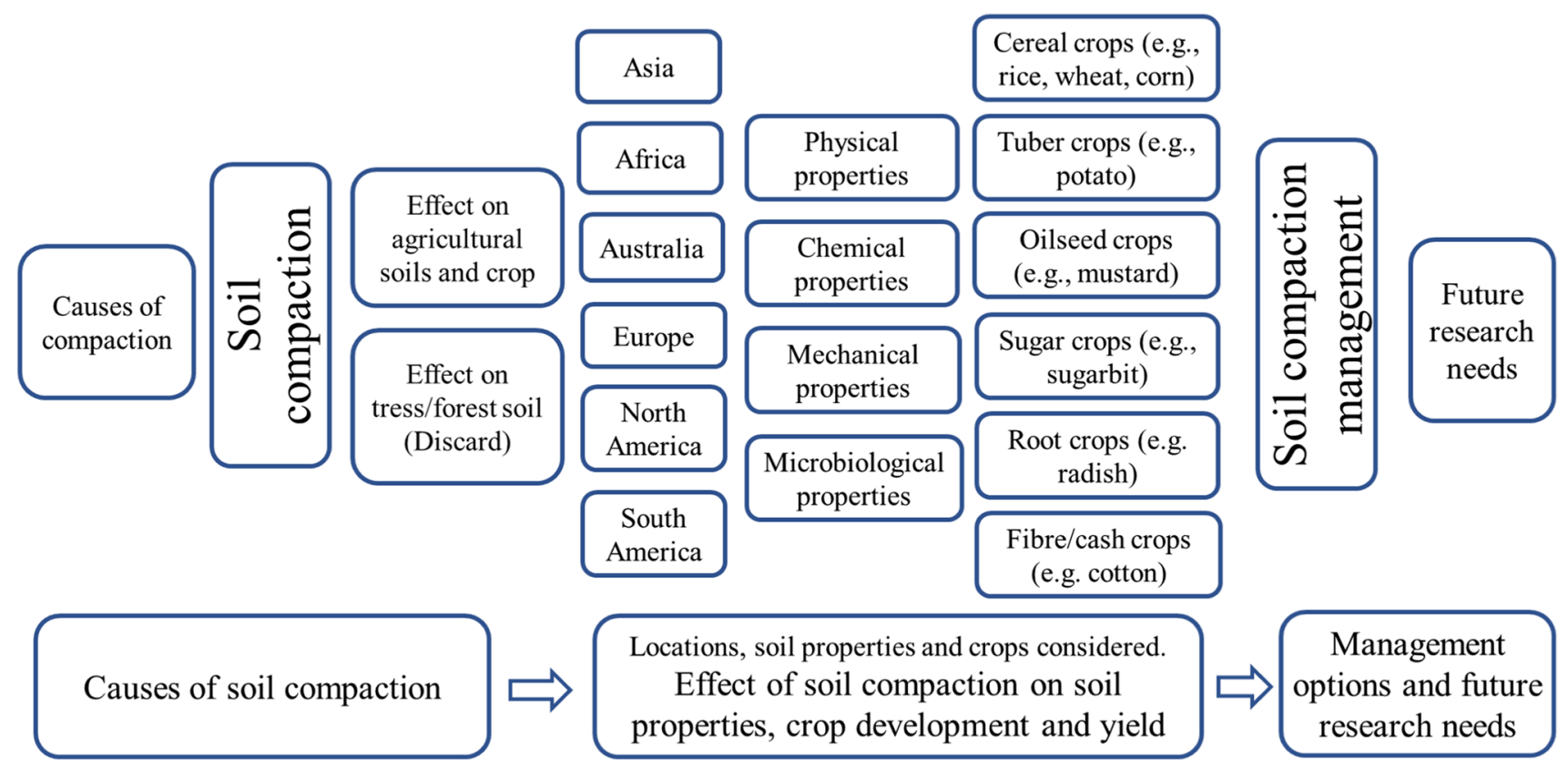

Fig. 3 Flow diagram of the search and selection procedure of the topics considered for the review 
especially in regard to commercial agricultural lands. The European Union (Jones et al., 2003) recognized soil compaction as a severe form of soil degradation. The severity of compaction is associated with land use and heavy machinery, indicating that it is the most ubiquitous kind of soil degradation in Central and Eastern Europe (Van den Akker $\&$ Soane, 2004).

Compaction is defined as the densification and distortion of soil by which total and air-filled porosity are reduced (Gregory et al., 2015). The Soil Science Society of America (SSSA) defines compaction as "the process by which the soil grains are rearranged to decrease void space and bring them into closer contact with one another, thereby increasing the bulk density (SSSA, 2008)." It alters the spatial arrangement, size, and shape of soil clods and eventually reduces pore space both inside and outside of clods and soil aggregates (Defossez \& Richard, 2002).

There are two types of compaction, viz., topsoil and subsoil compaction. Both are equally significant in the study of soil compaction and management. Kirby (2007) reported that topsoil compaction is associated with stresses imposed by the tire, track, or animal hoof on the soil surface, while subsoil compaction is related to the excessive stresses induced by vehicle load. Lamandé and Schjønning (2010), while assessing soil compaction, reported that stresses applied on the surface of the soil are influenced by tire inflation pressure (evaluated pressure for two tire widths of 560 and $800 \mathrm{~mm}$ ) and at $900 \mathrm{~mm}$ soil depth by vehicle wheel load (30 and 60 $\mathrm{kN})$. Subsoil compaction is recognized as highly persistent (Berisso et al., 2012; Schjønning et al., 2013) and leads to the deterioration of soil physical properties. As a result, subsoil compaction has an impact on functions and ecological services. These undesirable changes in soil structure further exacerbated the impact on crop growth and development, yield, and soil productivity (Lamandé \& Schjønning, 2018).

\section{Causes of Soil Compaction}

Soil compaction can occur due to both natural and anthropogenic practices (Kirby, 2007). Dense soil layer, soil properties inherited from rock and minerals, presence of higher clay content, environment (wet and dry years) and climate, shrinkage of soil due to drying, trampling by draft, and animal grazing are some of the natural causes of compaction (Van den Akker, 2006; Kirby, 2007; Houšková \& Montanarella, 2008; McKenzie, 2010). Wheels and tracks of machinery and soil-engaging tools (Canillas \& Salokhe, 2002), heavy machinery, intensive cropping, adopting nonjudicious soil management practices, and working with wet soil are examples of anthropogenic or human-induced causes of soil compaction (Hamza \& Anderson, 2005; Keller et al., 2019).
Soils with good structures have a greater water holding capacity compared to soils where the structure is damaged. High soil strength influences water and gaseous transport, water flow, soil biological activity, and mechanical strength, which can be altered due to soil compaction (Berisso et al., 2013; Chen et al., 2014). However, deep plowing resulted in a loose soil layer which showed a higher soil water holding capacity than the reduced soil tillage (Kroulík et al., 2007). Soil compaction reduces pore volume and changes pore size and distribution, connectivity, and tortuosity, decreasing gaseous and fluid transport capability and water holding capacity in the soil (Zhang et al., 2007). Repeated wheeling or higher soil stress due to wheel traffic results in deterioration of soil structure by increasing rearrangement of soil aggregates or particles (Horn et al., 2003). This resulted in lower hydraulic conductivity and higher BD at depths of 0-350 mm (Horn et al., 2003) and 0-75 mm, respectively (Blanco-Canqui et al., 2010).

\section{Factors Affecting Soil Compaction}

Soil compaction varies across most fields. The key factors affecting soil compaction include soil texture; soil moisture/ wetness; soil strength; type and weight of agricultural equipment, tillage layer, tire type, and inflation pressure; and the number of traffic passes (Salokhe \& Ninh, 1993; Eliasson, 2005; Hamza \& Anderson, 2005; Sakai et al., 2008; Han et al., 2009; Gerasimov \& Katarov, 2010). Multiple passes in the field with a heavy tractor (wheel loads $8 \mathrm{Mg}$ ) increase the risk of severe soil structural damage deep into the subsoil (Pulido-Moncada et al., 2019). Subsoil structures with coarse, medium, and medium fine-textured soils are weak and more susceptible to compaction (Spoor et al., 2003).

Both weather and climate also influence soil compaction. Soil structural deformation due to field trafficking increases with soil MC and the number of vehicle passes (Hakansson \& Lipiec, 2000). Equipment wheel load, tire contact area (machine type), soil wetness during field operations, and the number of passes of wheels (cumulative stresses) significantly influence the extent of soil compaction (Alakukku et al., 2003). Response of soil to high axle loads may vary across soil type and fields. However, some influencing factors such as soil MC, traffic events, equipment-tire configurations, tire inflation pressures, and weather events can exacerbate the response of the soil and degree of compaction (Shaheb et al., 2021). Soil compaction in wet years reduced crop growth and yield. But during the dry years, soil compaction was reported to have a positive influence on crop yield compared to non-compacted soils (Raper, 2005). Moist soils have a lower ability to resist vehicular compaction (Chamen et al., 2015). It is because the degree and magnitude of soil compaction depend on soil strength, which is related to the mechanical strength of soil (determined by 
soil texture and soil organic matter (OM) content), tillage layer, and wetness of soil (Hamza \& Anderson, 2005). The effect of compaction becomes severe under higher soil moisture deficits, which restrict rooting depth; in contrast, when moisture deficit is low, it may have a negligible impact at the same degree of soil compaction (Batey, 2009).

\section{Measurement of Soil Compaction}

Dry BD, PR, and total porosity of soils are frequently used to measure the degree of compaction. Koolen and Kuipers (1983) reported that the degree of soil compaction could be expressed by pore space, void ratio, dry volume weight, and bulk weight volume. However, the two key parameters, soil $\mathrm{BD}$ and $\mathrm{PR}$, are often used to determine and describe the levels of soil compaction throughout the soil profile (Soane et al., 1987; Duiker, 2002; Hatley et al., 2005; Raper, 2005). Soil cone penetrometer device with a $30^{\circ}$ circular cone (ASABE S313.3) is used to characterize the PR of soils and standard protocol (ASABE Standards, 2013, 2018) for data recording and analysis has been followed in most of the published articles on soil compaction. However, it is important to address soil properties and management data when soil PR is presented to describe and better understand the effect of compaction. The most common data are soil type/texture (\% clay), OM, soil moisture content (MC), BD by soil layer, cropping/tillage history, soil moisture retention curve, drainage condition, plasticity limit, and size of soil structural units (clods) (ASABE Standards, 2013). The critical values of soil PR that can restrict crop root growth are considered to be between 1.50 and 3.00 MPa (Hakansson, 2005); albeit the value is not constant, the lower threshold value was also reported to be $1.38 \mathrm{MPa}$ (Kulkarni et al., 2010). It is because the level of resistance is influenced by several variables such as soil structure, soil texture, moisture, clay content, and SOM (Reichert et al., 2009). Nutrient uptake of wheat and sorghum decreased due to subsoil compaction in sandy clay loam soil with an increase in soil BD (+17\%) from 1.65 to $1.93 \mathrm{Mg} \mathrm{m}^{-3}$ and PR from 1.00 to $4.83 \mathrm{MPa}$ (Ishaq et al., 2001a, 2001b). Cone index values $>2 \mathrm{MPa}$ have been shown to restrict varying magnitudes of crop root growth, development, and yield (Aase et al., 2001; Hamza \& Anderson, 2005). Soil PR is negatively correlated with crop yield. For example, soybean yield decreased with an increase in the PR of soil (Sivarajan et al., 2018). Air-filled porosity of $10 \%$ $(v / v)$ limits soil aeration and soil PR of $3 \mathrm{MPa}$ is often considered critical to the root growth and development of crops (Hakansson \& Lipiec, 2000; Lipiec \& Hatano, 2003).

Visual assessment of soils is every so often used to explain soil compaction. Evaluation of soil profiles by conducting soil survey, visual assessment of porosity and soil strength, examination of the plant root system, and semiquantitative visual and tactile methods can help to describe soil compaction (Spoor et al., 2003; Hatley et al., 2005; Batey, 2009; Munkholm et al., 2013; Obour et al., 2017). Rickson et al. (2012) described seven soil quality indicators (SQIs) that could be used to monitor and measure changes in soil condition or quality in agricultural soils due to compaction. These seven SQIs are soil depth, surface sealing, visual soil evaluation, packing density (e.g., data on bulk density and clay content), aggregate stability, soil water retention properties, and soil erosion rate.

Remote sensing technology has been used to determine and understand soil compaction in temporal and spatial scales. The effect of compaction on silty loam soil was investigated by analyzing plant reflectance response (Kulkarni et al., 2010). The results showed that there was a significant correlation between green normalized difference vegetation index (GNDVI) and soil compaction (e.g., PR of hardpan). Klopfenstein (2016) used remote sensing imagery to determine soil compaction and reported that the predicted model for yield estimation was consistent for wheel trafficked (undercarriage) compaction, suggesting that the remote sensing could be used to assess soil compaction. A recent study (Khanal et al., 2020) reported the possibility of using remote sensing tools for measuring the impact of soil compaction on soil and crop.

X-ray computed tomography (X-ray CT) has been used as a potential tool to investigate the effect of soil compaction and possible modifications in soil structure and other physical properties of soil (Rachman et al., 2005; Mooney, 2006). It is a very useful technique to quantify soil structure, pore characteristics, BD and water content, pore size and pore size distribution, and orientation, which can help to improve the overall understanding of hydrodynamic behavior of soils (Taina et al., 2008; Rab et al., 2014; Beckers et al., 2014; Pires et al., 2020). X-ray CT was used to show visual differences in the soil structure of undisturbed soil cores and quantification of pore characteristics of compacted and uncompacted soils under different tire inflation pressures and tillage systems in sandy loam and silty clay loam soils in the UK and the USA, respectively (Millington et al., 2016; Shaheb et al., 2020).

\section{Benefits of Soil Compaction}

Most of the published literature indicates that compaction changes soil structure, which adversely impacts crop growth and development. Nevertheless, some positive effect of soil compaction has also been reported. Soil compaction increased root and shoot mass of oilseed rape and narrowleafed lupine (Trükmann et al., 2008). The incidence of soil degradation and compaction is reported in some agricultural soils in Scotland (Towers et al., 2006). But, there is no evidence of a serious threat to soil quality in those soils. Instead, the circumstances are recognized to be localized and 
could be readily remedied (Towers et al., 2006). However, depending on soil types, a small degree of topsoil compaction is beneficial for crop root anchorage and growth (Bouwman \& Arts, 2000; Hamza \& Anderson, 2005). Moderate compaction facilitated better seed contact with soil particles, which increased corn emergence compared to un-trafficked crop rows, but no significant differences were reported on the yield of corn and the growth and yield of soybean (Sivarajan et al., 2018).

\section{Effect of Soil Compaction on Soil Properties}

Equipment size and multiple passes of heavy machinery can deform the soil and increases the degree of compaction. Compaction reduces soil productivity and deteriorates soil functions through increased water runoff and soil erosion (Dejong-hughes et al., 2001; Huber et al., 2008). Several other published reports have indicated that soil compaction due to field traffic reduces soil porosity, hydraulic conductivity, and water infiltration rate while increasing soil strength and soil BD (Raper \& Kirby, 2006; Radford et al., 2007; Blanco-Canqui et al., 2010; Hamza et al., 2011; Ji et al., 2013). PR and BD of soils increase with the increase in soil compaction, resulting in a decrease in soil air permeability in wheel tracks and trafficked crop rows compared with no tracks and un-trafficked crop rows (Kaspar et al., 2001; Sweeney et al., 2006; Shaheb, 2020).

Field traffic intensity and high ground pressure have an impact on soil physical properties. Increased axle load (from 1 to $3 \mathrm{kN}$ ) and tractor passes cause a significant increase in compaction (Salokhe \& Ninh, 1993). The report also highlighted that the maximum compaction of soil took place after the first pass of the tire-wheel, and in later passes, it decreased exponentially. The first tire pass in the soil increased the BD and PR of soil an average of 7 and 6\%, respectively, compared to zero passes (Canillas \& Salokhe, 2002). It has been estimated that the first traffic pass may cause up to $90 \%$ of compaction damages in soil (Badalıkova, 2010). The effect of multiple passes of tractors on the PR of soil is shown in Fig. 5.

A 4-year compaction study conducted in Denmark on a sandy loam soil showed that wheel loads $(8 \mathrm{Mg})$ with 4-5 multiple passes significantly increased soil BD and also changed subsoil structural quality, air permeability, air-filled pore space, gas diffusivity, and pore volume to $>50 \mathrm{~cm}$ soil depth as compared to multiple passes with $3 \mathrm{Mg}$ wheel loads and zero compaction treatments (Pulido-Moncada et al., 2019). Wheel traffic can cause more negative impacts on soil conditions than intensive cropping systems. Wheel traffic resulted in an increase in soil BD by $19 \%$ (from 1.16 to $1.38 \mathrm{Mg} \mathrm{m}^{-3}$ ), PR by $74 \%$ (from 1.78 to $3.10 \mathrm{MPa}$ ), shear strength by $165 \%$ (from 23 to $61 \mathrm{kPa}$ ), and aggregate tensile strength by $153 \%$ (from 377 to $955 \mathrm{kPa}$ ) over zero-trafficked soils at depths 0-75 mm (Blanco-Canqui et al., 2010). Conventional tillage caused a high number of tire passes on soil, and $>86 \%$ of the total area was reported to be trafficked during one cropping season (Kroulík et al., 2011). The total runover areas for two and three repeated traffic events for the conventional tillage systems were 31 and $15.6 \%$, respectively (Kroulík et al., 2011). In general, the repeated traffic resulted in significant damage to soil structure and caused deterioration of soil properties (Hula et al., 2009; Kroulík et al., 2009; Pulido-Moncada et al., 2019). A recent soil compaction study was conducted by Shaheb et al. (2020) in a typical corn and soybean rotation in Illinois. The results showed that the field operations performed by tillage tractor
Fig. 5 Effect of soil compaction due to combine harvester traffic $(14.5 \mathrm{Mg})$ on penetrometer resistance of plowed silty loam soil, Wisconsin. Adapted from Wolkoski and Lowery (2008)

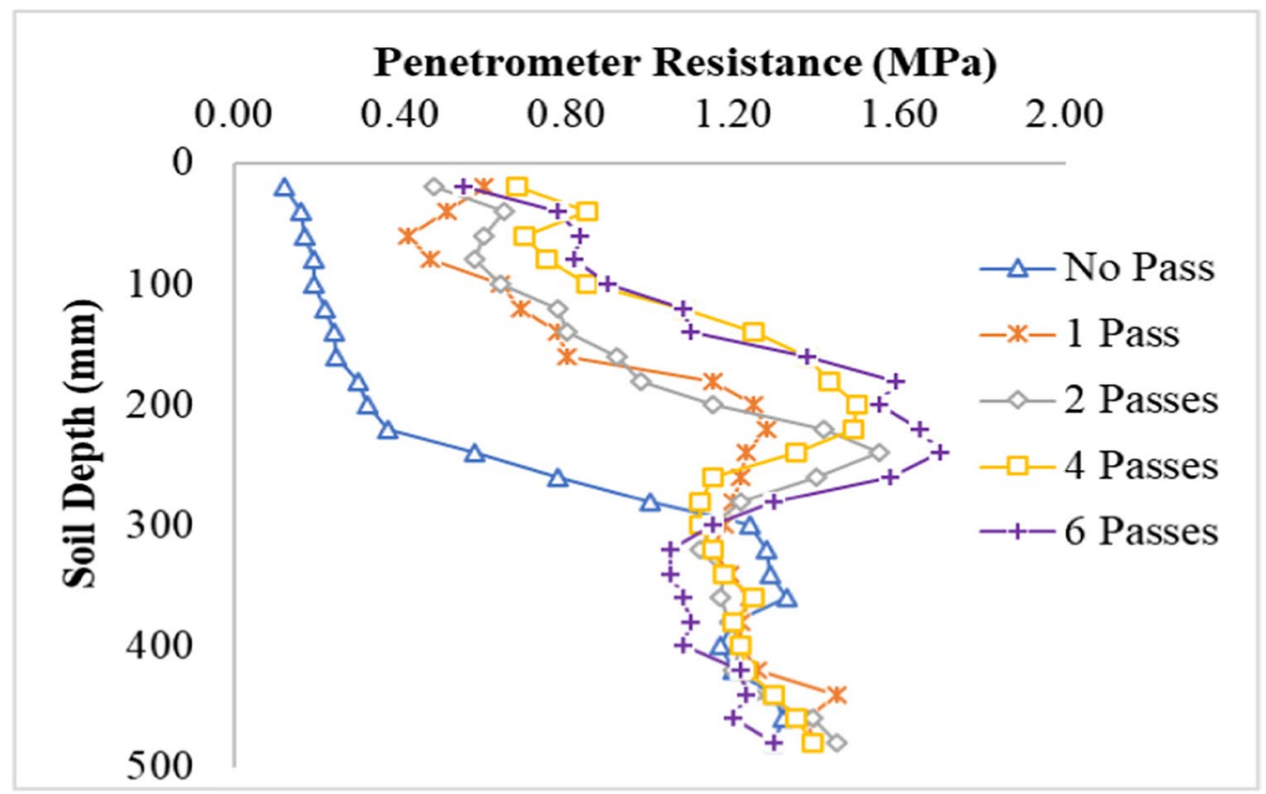


(JD7930, 10.3 Mg), planter tractor (JD7700, $8.63 \mathrm{Mg}$ ), and a combine harvester (JD9410, 18.14 Mg) caused approximately $75.2,57.6$, and $57.5 \%$ of the area to become trafficked for deep tillage, shallow tillage, and no-till systems, respectively (Fig. 6).

The total porosity as a measure of soil compaction was lower for the high inflation pressure tire system (0.17 MPa) compared to the track and low tire pressure systems $(0.04 \mathrm{MPa})$ on a silty clay loam soil in Illinois (Hoeft et al., 2000; Duiker, 2004b). Under low inflation pressure tires, soils had a $17.9 \%$ greater number of macropores than that of the standard inflation pressure tires in Drummer silty clay loam soils in Central Illinois (Shaheb et al., 2020). Increased field operations using heavy machinery damaged soil structure which is exacerbated when operating in wet soil with high ground pressure (Botta et al., 2010). Low tire inflation pressure systems reduce the topsoil stresses at a depth of $10 \mathrm{~mm}$, while increased axle load increases subsoil stresses (Arvidsson \& Keller, 2007). The benefit of using tires with lower inflation pressures $(0.19$ to $0.22 \mathrm{MPa}$ ) in reducing soil PR (0 to $700 \mathrm{~mm}$ depths) was significant as compared to tires with higher inflation pressure (0.25 MPa) (Antille et al., 2013). A multi-year study on fine clay soil showed that topsoil structural damage resulted from high ground pressure tires while large axle loads tend to cause the most significant compaction in subsoils (Botta et al., 2010). The ground pressure of $200-250 \mathrm{kPa}$ also reduced soil water infiltration in compacted soils by more than $80 \%$ compared to un-compacted soil (Chyba et al., 2014). However, depending upon the severity, soil compaction can drastically reduce water infiltration rates, increasing the run-off problems, diffuse pollution, and flooding (Godwin et al., 2019).

\section{Effect of Soil Compaction on Agricultural Productivity}

Studies were conducted during the early 1940s and 1950s to understand the effect of compaction. These results showed that plant growth and development substantially reduced or restricted under severe compaction (Schafer et al., 1992). Reduced crop growth, decreased stomatal conductance and functions and photosynthesis and enhancement in membrane injury are the first responses by environmentally stressed plants (Ripley et al., 2007). Soil compaction leads to a reduction in crop growth and yield because it restricts crop root systems from penetrating through the compacted soil and extracting soil-bound water (Hula et al., 2009). The wheel track/machinery traffic-induced soil compaction in a soybean crop field is shown in Fig. 7.

\section{Effect of Soil Compaction on Crop Growth and Development}

\section{Plant Establishment}

Soil compaction reduces crop establishment by increasing soil strength. Plant emergence of corn (Tolon-Becerra et al., 2011; Shaheb, 2020) and barley (Millington et al., 2016) was impaired due to compaction, but the partial effect on plant emergence of soybean (one out of three years) was also reported (Shaheb et al., 2018). Compaction induced by high tire inflation pressure $(700 \mathrm{kPa})$ decreased plant population in no-till soybean and corn production (Sidhu \& Duiker, 2006). Lower plant establishment and root dry mass of winter barley in compacted areas were associated with anaerobic conditions as a result of the reduced size of soil
Fig. 6 Estimated area of field trafficking for three typical tillage systems (assumed 33.3\% split between tillage systems) experiment in Champaign County, Illinois (Shaheb, 2020)

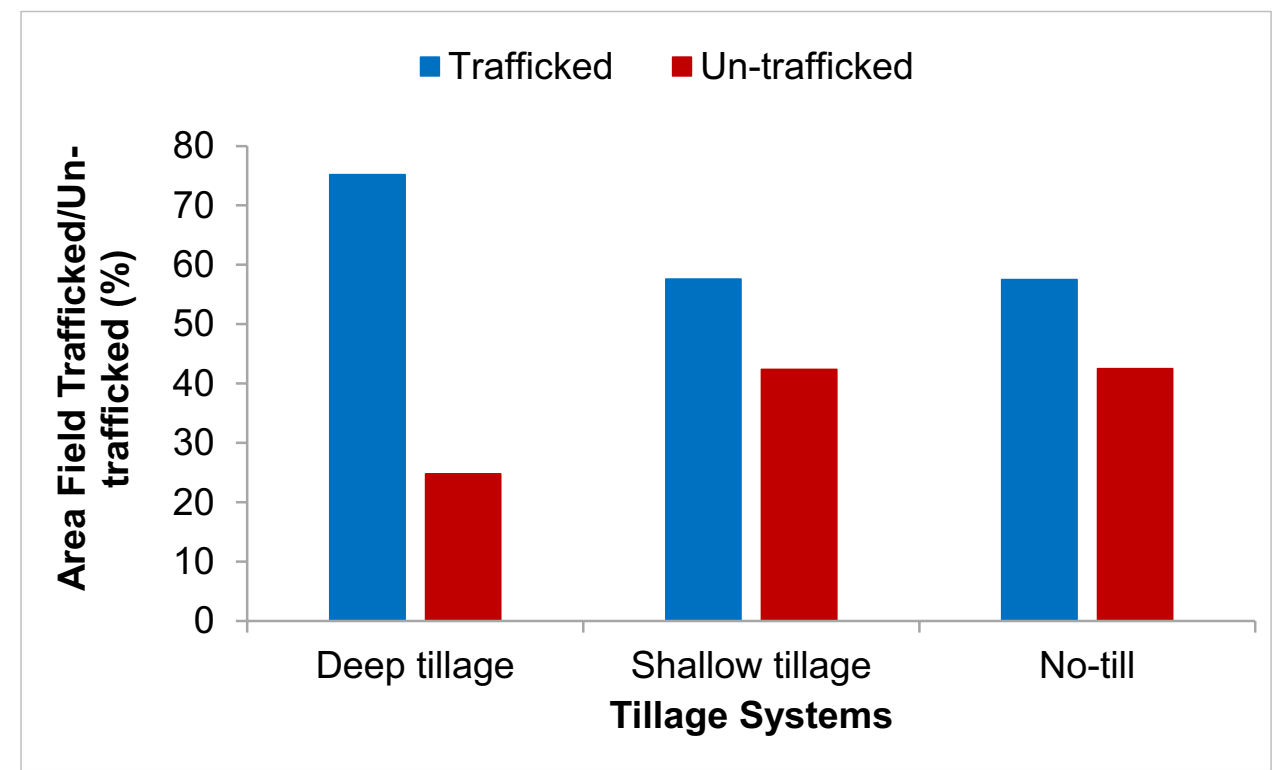




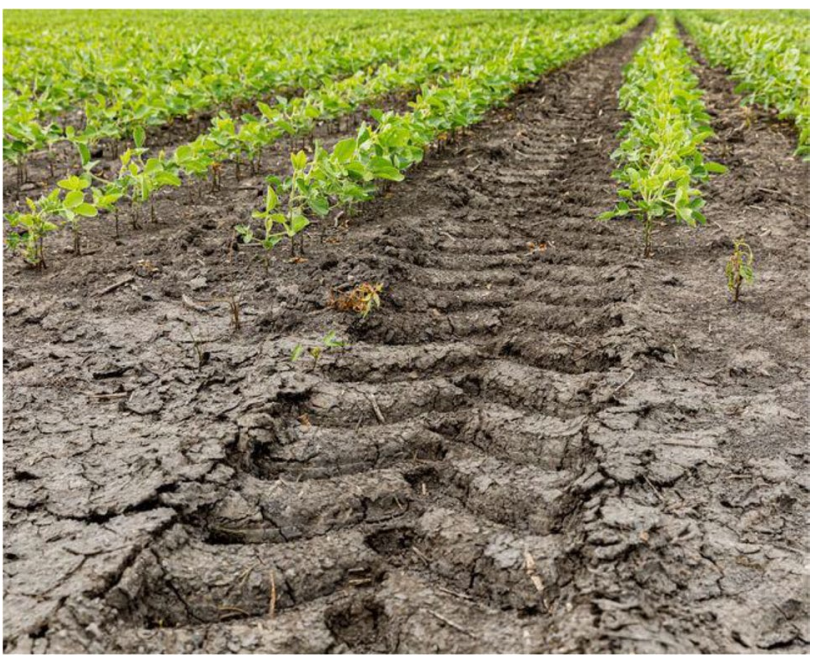

Fig. 7 Soil compaction due to machinery traffic in a soybean crop field. Source: Gruber (2021)

pores (Millington et al., 2016). Furthermore, several other studies reported that soil treatments with subsoiling/deep tillage for alleviating compaction had an adverse effect on subsequent crops' germination (Ishaq et al., 2001a, 2001b; Defossez \& Richard, 2002; Gelder et al., 2007).

\section{Plant Height}

The effect of soil compaction on plant height was noticeable. Crops suffer more during the early stages of their growth due to soil compaction (Abu-Hamdeh, 2010; Millington et al., 2016). Plant height of corn significantly reduced by $21 \%$, 42 days after planting, and $11 \%$ at harvest due to annual road tire compaction compared to control (Sidhu \& Duiker, 2006). Compared with the zero load treatment, corn plant height for the 8- and 19-Mg loads treatments was decreased by 5 and $10 \%$ in the first year and 5 and $6 \%$ in the second year, respectively (Abu-Hamdeh, 2010). A recent study in Illinois showed that corn height was reduced due to compaction by high/standard inflation pressure tire systems in the first two years, while for soybean, the effect was significant in the third year (Shaheb, 2020).

\section{Crop Vegetative Growth}

Crops growing in compacted soils exhibited reduced morphological and physiological functions. The restricted root growth due to compaction might decrease leaf expansion and stomatal conductance (Lipiec \& Hatano, 2003), crop growth, yield, and quality (Hassan et al., 2007; Chen \& Weil, 2010). The most significant morphological effects of soil compaction in crops are stunted growth, reduced plant height and stem diameter, decreased nutrient uptake, reduced leaf gas exchange, and increased thickness of epidermal cells and cell walls (Clark et al., 2003; Grzesiak et al., 2013; Shah et al., 2017b). Decreased carbon assimilation, less translocation of photosynthates due to high mechanical impedance impacted the corn root system, which resulted in reduced growth of corn (Tubeileh et al., 2003; Shah et al., 2017b). High annual traffic intensity causes a significant reduction in soil aeration and limited oxygen in the root zone that results in a decrease in root and crop growth and yield (Hakansson, 2005; Chamen, 2011). The effect of soil compaction in Fig. 8 shows that compaction of soil is not only reduced plant height and growth of corn but also delayed its days to flowering (Dyck, 2017).

\section{Crop Root Systems and Growth}

Soil compaction can reduce root growth and development, and as a result, they impact crop productivity. But, its effect on crop growth and development is complex and can be influenced by axle load, tire inflation pressure (Abu-Hamdeh, 2010), dry, and wet weather conditions (Galambošová et al., 2017). Soil compaction impacts crop root length, its growth, distribution, and function (Ishaq et al., 2001b). Reduced plant growth and development were reported in soils with high strength (Rosolem et al., 2002; Gebauer \& Martinková, 2005; Bengough et al., 2006). Root growth and development of canola and wheat were significantly reduced under wheel tracks (Chan et al., 2006). Soil compaction significantly reduced the length of seminal adventitious roots, total number, and length of lateral roots of both corn and triticale (Grzesiak, 2009). Soil PR values above $2.00 \mathrm{MPa}$ showed restricting crop root development at varying degrees (Aase et al., 2001). Stunted root growth, poor root proliferation, and reduced availability of nutrients might be associated with a significant reduction in soil porosity, pore size, and soil aeration (Dexter, 2004; Nawaz et al., 2013). Soil

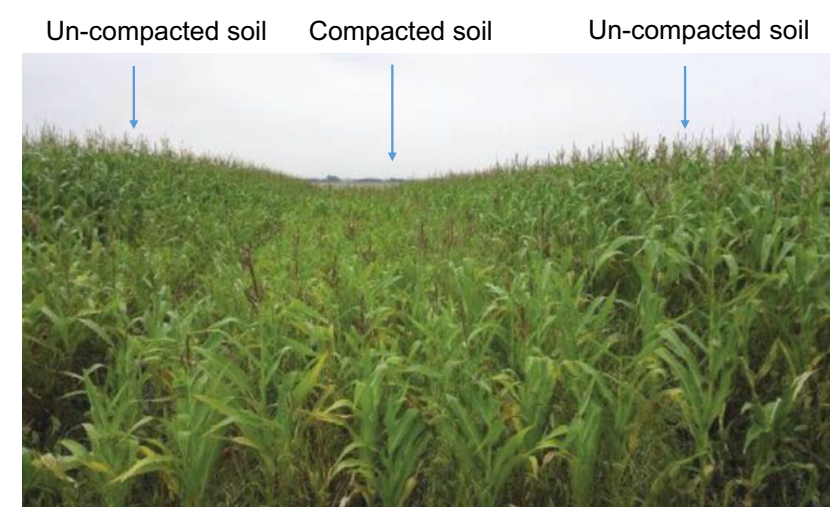

Fig. 8 Effect of soil compaction on corn growth and development in Ohio. Source: Fulton and Shearer, The Ohio State University cited by Dyck (2017) 
compaction (BD $1.60 \mathrm{Mg} \mathrm{m}^{-3}$ ) coupled with waterlogging had harmful effects on the root and shoot growth of wheat (Wu et al., 2018). Reduced growth and yield of potato (Stalham \& Allen, 2001) and poor root system development in tomato (Tracy et al., 2012a), and reduced root dry matter (DM) of soybean were also observed due to soil compaction (Botta et al., 2010). High soil penetration resistance and mechanical injury to taproots of plants, and less nutrient availability due to soil compaction could be the reasons for reduced root growth in cover crops (Rosolem et al., 2002). The effect of compaction on the root length of some cereal crops is shown in Fig. 9.

\section{Crop Lodging}

Crop lodging results in decreased crop productivity. When the aboveground parts of crops are exposed to the storm, lodging occurs, which is mainly due to a poor root system. Crop yield losses due to lodging range from 3 to $25 \%$, and in severe cases, it could be higher (Sui-Kwong et al., 2011; Shah et al., 2017a). Soil compaction resulting from conventional tillage caused a poor root system in corn that considerably increased lodging in heavy loamy soil (Bian et al., 2016). Depending on soil types, compaction had a positive impact on root system development in some crops. Soil compaction due to surface rolling in seedbeds resulted in increased soil strength and correspondingly increased plant emergence, root establishment, and growth of wheat (Atkinson et al., 2009). Higher resistance to lodging was observed in winter barley because of the greater anchorage strength of its root system (Scott et al., 2005). Improved contact between roots and surrounding soils in compacted areas (BD $1.50 \mathrm{Mg} \mathrm{m}^{-3}$ ) increased root density and root diameter over less compacted soil (BD 1.10 $\mathrm{Mg} \mathrm{m}^{-3}$ ) (Tracy et al., 2012b).

\section{Plant Nutrient Uptake}

Soil factors such as PR, pore distribution, and water and nutrient availability had the most considerable effect on root growth (Hoad et al., 2001). Mechanical impedance restricts root growth, limits root access, and decreases the plant roots' ability to uptake nutrients (Passioura, 2002). This might also be due to an increase in BD and reduced pore size in soil (Nawaz et al., 2013; Sadras et al., 2016). Subsoil compaction caused a significant reduction in nutrient uptake by $12-35 \%$ for nitrogen $(\mathrm{N}), 17-27 \%$ for phosphorus $(\mathrm{P})$, and up to $24 \%$ for potassium $(\mathrm{K})$ in wheat, while in sorghum, the reduction of N, P, and $\mathrm{K}$ was $23 \%, 16 \%$, and $12 \%$, respectively (Ishaq et al., 2001b). As a result of decreased nutrient uptake, there were increased denitrification or leaching losses of applied nitrogen fertilizer resulting in reduced $\mathrm{N}$ efficiency (Lipiec et al., 2003a; Ruser et al., 2006; Gregorich et al., 2011). Low water infiltration and fewer macrospores account for reduced root growth and lower $\mathrm{N}$ uptake in compacted soil (Rosolem et al., 2002). Even though the storage and availability of $\mathrm{N}$ were greater in compacted soils, plant $\mathrm{N}$ uptake was restricted (Gregorich et al., 2011). Soil P is relatively immobile, and therefore, its uptake in compacted soil is mostly influenced by the root system architecture. The application of higher fertilizers rates to address lower crop yields increases the potential for nutrient loss. However, increased soil PR, decreased root distribution pattern, and root elongation ultimately lead to restricted root access to water and plant nutrients in compacted soil (Lipiec et al., 2012;
Fig. 9 Root length of cereals seven days after planting under un-compacted (U) and compacted (C) soil. Mean with the different letters within the same plant species are significantly different $(P<0.05)$. Adapted from Lipiec et al. (2012)

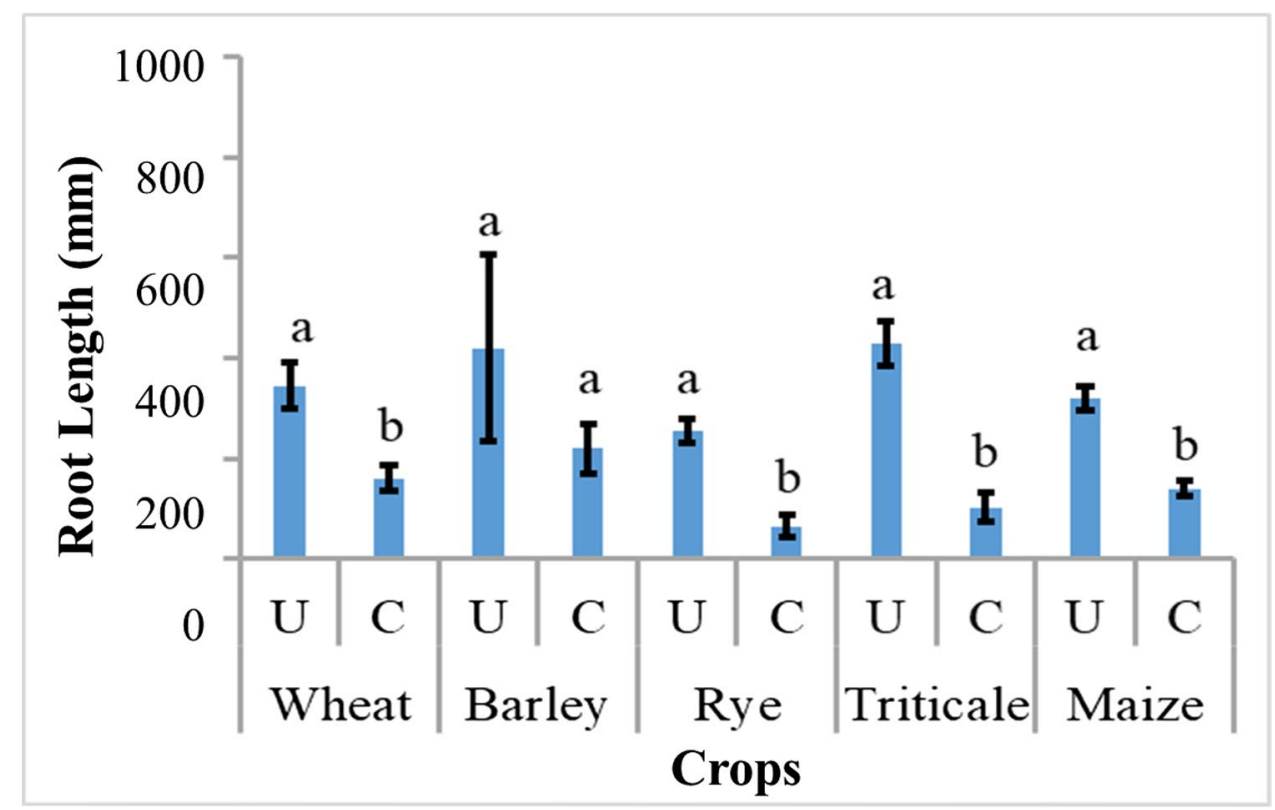


Nosalewicz \& Lipiec, 2014; Siczek et al., 2015; Colombi et al., 2017).

\section{Plant Water Uptake}

Soil compaction reduces water infiltration rate, the number of soil pores, and total porosity, and thus, it may affect plants to access water and nutrient pools. High soil water content results in aeration problems. This slows drainage and accelerates to an anaerobic root environment, which in turn restricts nutrient uptake by plants (Dejong-hughes et al., 2001). Sudibyo (2011) reported that a decrease in water and fertilizer use efficiencies are the immediate consequences of soil compaction in conventional agriculture. Root density and water uptake from compacted clay loam soil are limited, suggesting that reduced water extraction may be rather a consequence than a cause for reduced plant growth (Amato \& Ritchie, 2002). Besides, the plant's leaf area decreases with an increase in soil compaction even though there were no signs of a shortage of water or nutrients in the soil (Passioura, 2002). However, moderate compaction with soil BD of $1.50 \mathrm{Mg} \mathrm{m}^{-3}$ led to an increase in root water uptake in soybean, corn, barley, and rice (Lipiec \& Hatano, 2003), while in wheat, it was $67 \%$ higher than heavily compacted soil with BD of $1.72 \mathrm{Mg} \mathrm{m}^{-3}$ (Nosalewicz \& Lipiec, 2014). In response to increased topsoil PR, corn root systems become shallower, and water uptake from the topsoil increases (Colombi et al., 2018). However, drying of topsoil leads to further increase in the soil PR; consequently, it impeds root and plant growth, reduces water uptake, and crop productivity in corn (Colombi et al., 2018). In an 8-year study, Blanco-Canqui et al. (2010) showed that wheel traffic had a significant effect in decreasing water infiltration, soil water retention, plant-available water, effective porosity, and volume of pores $(>50 \mu \mathrm{m})$. Stresses such as water deficits or soil compaction restricts crop rooting depth (Batey, 2009) and decrease the development of crop canopy and root systems' capacity and efficiency to capture and use resources such as water, carbon dioxide, radiation, and nutrients (Sadras et al., 2016). Water uptake of wheat decreased in response to the heavily compacted subsoil. However, the effects were partly minimized by increased water uptake from looser topsoil layers (Nosalewicz \& Lipiec, 2014).

\section{Effect of Soil Compaction on Biomass and Crop Yield and Economics}

Soil compaction decreases biomass and crop yield by reducing crop growth and development. Studies in various soil types and environments showed that DM and yield of crops decreased significantly in compacted soils due to heavy machinery, higher axle load, and repeated field trafficking as compared to light equipment, lower axle load, and un-compacted soil (Voorhees, 2000; Ishaq et al., 2001b; Sidhu \& Duiker, 2006; Chan et al., 2006; Abu-Hamdeh, 2010; Whitmore et al., 2011). Crop growth and productivity of corn decreased substantially due to soil compaction. Corn DM decreased by $26 \%$ and yield by $33 \%$, respectively, and was attributed to adverse soil physical conditions resulting from compaction rather than limited $\mathrm{N}$ fertility (Gregorich et al., 2011). The effect of soil compaction, depending upon its severity and magnitude, can significantly reduce crop yields by 10 to $15 \%$ (Godwin et al., 2019). Subsoil compaction with vehicle axle load $(11 \mathrm{Mg})$ followed by tillage caused a 15 to $43 \%$ reduction in corn yield (Voorhees, 2000 ), while $17 \%$ reduction was observed due to compaction caused by tillage with two-wheel passes ( $8 \mathrm{Mg}$ axle load) and 300-kPa tire inflation pressure (Abu-Hamdeh, 2010). In a 5-year study conducted in a silty loamy soil in Kentucky, crop yield generally increased in soils subject to deep tillage at $400 \mathrm{~mm}$. However, precision tillage treatments had a higher crop yield at the same depth compared to deep tillage at $400 \mathrm{~mm}$ at one site out of three study sites (Wells et al., 2005).

Crop response may vary due to dry and wet soil conditions. Results from a 17-year long-term study showed that yield reduction in subsoil compaction in clay soil was higher in wet seasons than in dry seasons (Alakukku, 2000). However, multiple machinery passes caused an approximately $33 \%$ crop yield loss in dry years compared to the single machinery pass $(5 \%)$ in years when there was no shortage of soil moisture (Galambošová et al., 2017). Soil compaction due to heavy equipment $(185 \mathrm{kN})$ caused severe grain yield reduction of soybean for three consecutive growing seasons (Botta et al., 2010). Crop yield loss has an impact on the profitability of farming systems. Decreased crop yield and less effective use of resources are the direct and indirect adverse economic effects of compaction (Botta et al., 2010; Chamen et al., 2015). Soils under the low incidence of compaction due to low tire inflation pressure had a higher crop growth and yield. As a result, there was a potential financial advantage compared to soils where compaction was caused by high tire inflation pressure (Stranks, 2006; Smith et al., 2014b; Shaheb, 2020). The effect of compaction on crop growth and yield in different farming systems are described in Table 1.

\section{Effect of Soil Compaction on Draft Force Requirement and Fuel Use}

Soil compaction influences the draft force and fuel use requirements of agricultural machinery. Besides soil degradation and soil erosion, soil compaction resulted in higher fuel consumption due to the higher rolling resistance of tires (Batey, 2009; Chamen et al., 2015). It is important to note that excessive fuel consumption depends on the machine 


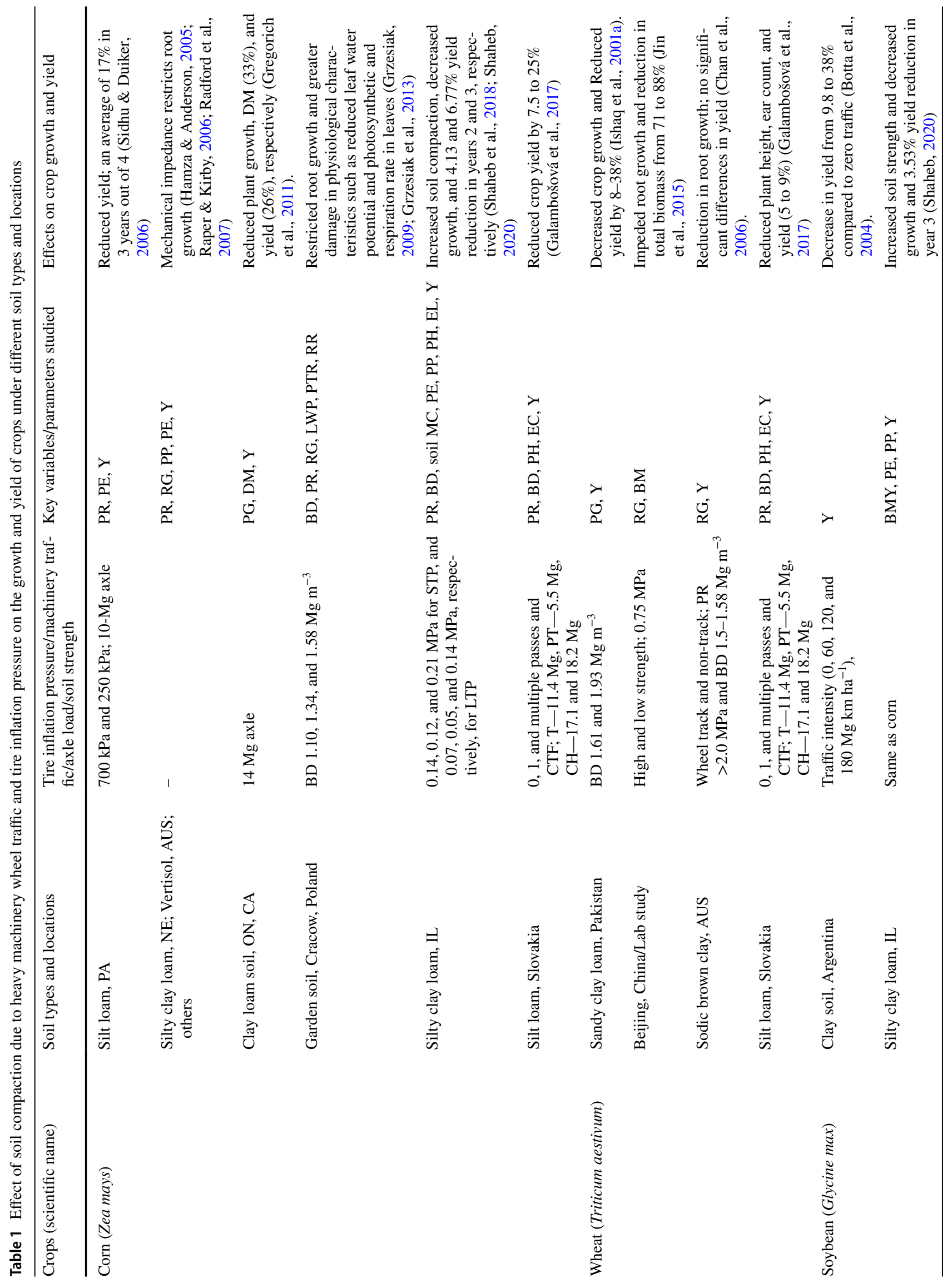




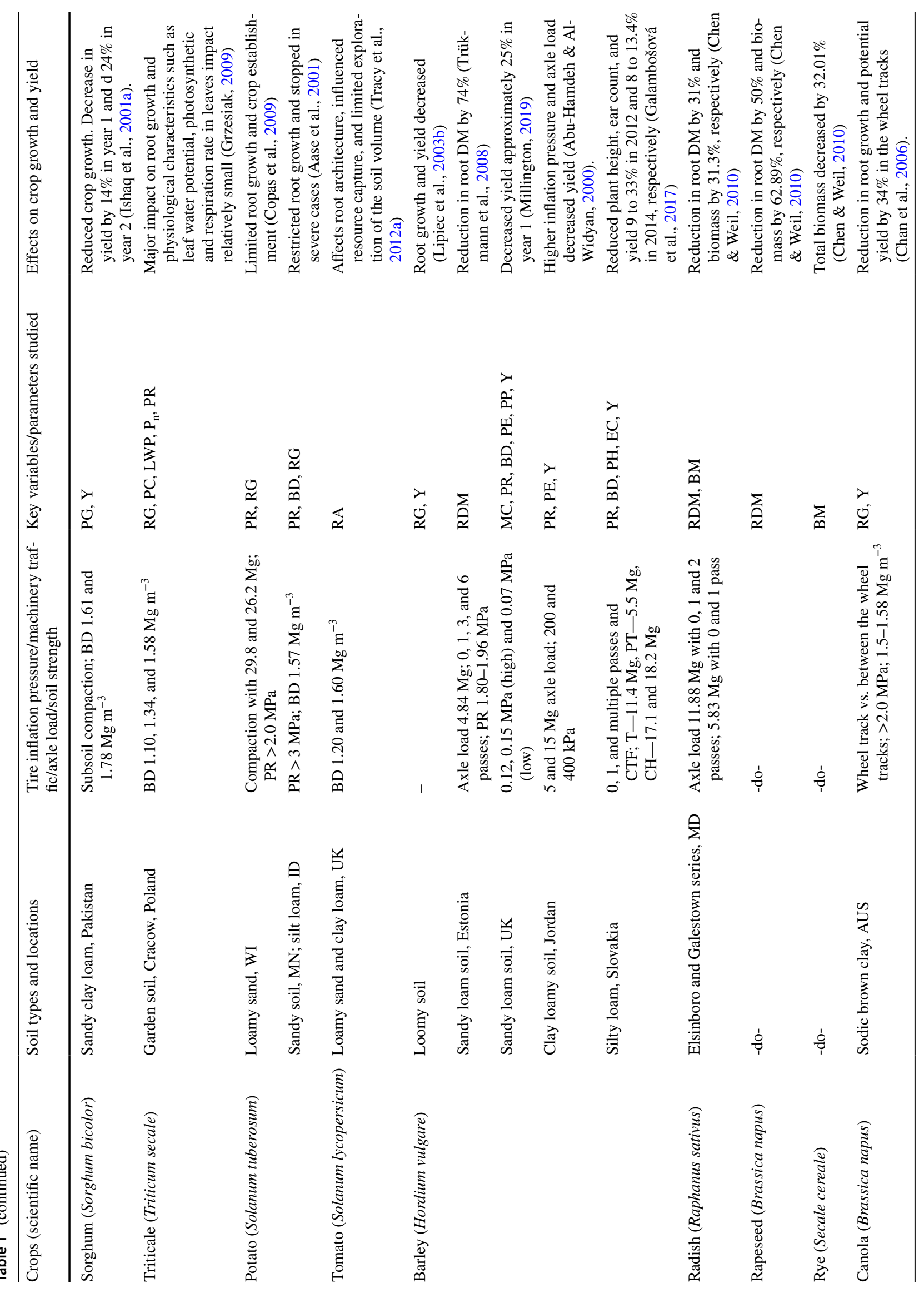


width, speed, size and weight of equipment and type and size of tires, tire inflation pressure, and time needed for field operations (Botta et al., 2010; Battiato et al., 2013). Increased fuel consumption and decreased work rate were reported due to field traffic with heavy equipment $(185 \mathrm{kN}$, $\left.9.5 \mathrm{~L} \mathrm{ha}^{-1}\right)$ as compared to the light equipment $(127 \mathrm{kN}$, $6.5 \mathrm{~L} \mathrm{ha}^{-1}$ ) (Botta et al., 2010). Heavier tractor (180 HP) consumes around $38 \%$ more diesel $\left(25 \mathrm{~L} \mathrm{~h}^{-1}\right)$ than a $120 \mathrm{HP}$ tractor $\left(18 \mathrm{~L} \mathrm{~h}^{-1}\right)$ (Nix, 2011). Subsoiling is used to remove soil compaction, but deep plowing results in loosened soil, which increases the risk of re-compaction of the subsoil (Soane et al., 1986).

Furthermore, managing compacted soil involves higher costs. As a result, energy consumption for tillage operations to manage compacted soil can be increased by $200-300 \%$ (Godwin et al., 2019) and 25-40\%, and half of tractor engine power was reported to be wasted (Tullberg, 2000; Tullberg et al., 2007). Consequently, soil compaction caused increased use of energy, cost, and risks of re-compaction, further deteriorating soil conditions, and caused additional adverse environmental consequences.

\section{Management Strategies to Alleviate Soil Compaction}

Improved root distribution and increased rooting depth are vital for better crop growth and yield. By following good soil management practices, which help with efficient uptake of applied nutrients by crops, growing deep-rooted crops in rotations and conservation tillage may help avoid or alleviate compaction. Prevention of soil compaction is far better than correcting compaction problem after it occurs (McKenzie, 2010), meaning it will be a win-win situation for improving farm productivity while simultaneously reducing environmental impacts (Hallett et al., 2012). However, the most commonly used strategies in minimizing compaction are avoidance, alleviation, subsoiling, controlled traffic, and acceptance (Dejong-hughes et al., 2001; Hamza \& Anderson, 2005; Botta et al., 2010). A comparison of the effect of compaction management and gross margin is shown in Fig. 10. Reducing wheel load, e.g., using dual or tandem wheels, high flexion tires, and reducing tire inflation pressure, may reduce the risk of compaction (Keller \& Arvidsson, 2004; Shaheb, 2020; Shaheb et al., 2021). Reducing tire inflation pressure has shown a positive effect on maintaining soil porosity and increased crop growth and yield (Smith et al., 2014b; Shaheb et al., 2018, 2020; Millington, 2019). Subsoiling contributed to a significant reduction of compaction and resulted in increased root growth of cotton and cover crops and cotton yield (Schwab et al., 2002; Busscher \& Bauer, 2003). Deep tillage with vehicle axle loads $\leq 10 \mathrm{Mg}$ and tire inflation pressures $<250 \mathrm{kPa}$ 
Fig. 10 A typical comparison of different compaction management strategies and their effect on gross margin of crops. After Chamen et al. (2015)

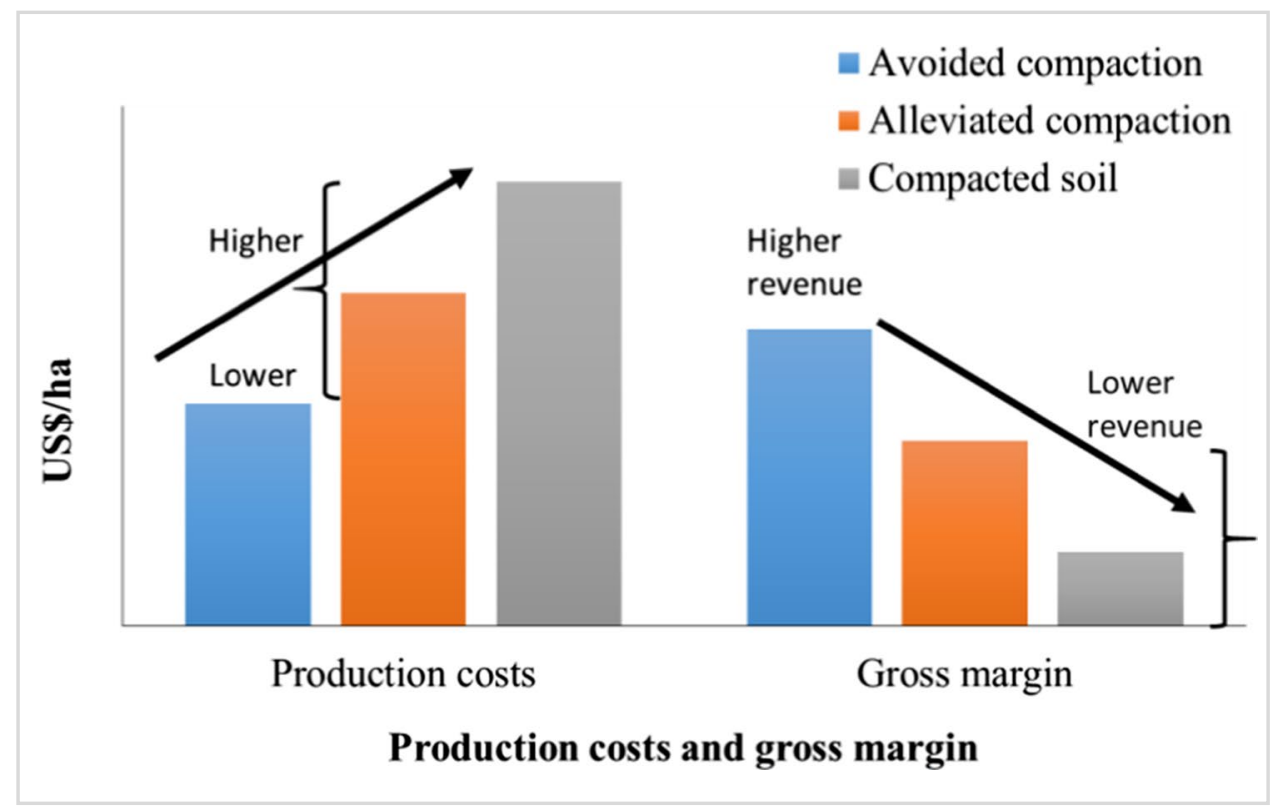

effectively reduced soil compaction (Sidhu \& Duiker, 2006). Detailed management strategies for dealing with soil compaction are described in Table 2.

\section{Conclusions}

Soil compaction is unfavorable for sustainable agriculture. It decreases the volume of a given soil mass by reducing the air-filled pore space. Soil compaction changes soil structure by increasing bulk density and penetration resistance and decreasing the total porosity of the soil. Use of heavy machinery for tillage operations, planting, pre- and postemergence spraying of crop protection chemicals, and harvesting crops can cause soil compaction. These field operations with high gross weight vehicles/machinery eventually can damage soil structure and deteriorate soil environment that are critical for sustainable crop production, leading to reduced crop growth and yield. Soil compaction alters plant root architecture and anchorage. As a result, reductions in plant nutrient uptake and growth are observed, resulting in a reduction in biomass and crop yield. Soil compaction resulting from the multiple passes of heavy machinery, with various combinations of wheel load and ground pressure, supports the following theoretical predictions: (a) high ground pressure significantly increases soil BD of topsoil but has less effect at greater depth and (b), conversely, increases in vehicle/wheel load, at a given ground pressure causes significant increases in compaction at deeper depths.

Compaction of soil results from the conventional vehicles and its subsequent effect on altering soil structure and reducing crop development exemplifies the significance of lowering gross vehicle weight to minimize soil compaction.
Use of appropriate machinery for field operations, subsoiling, tracked vehicles, and site-specific deep tillage treatment could reduce soil compaction. High flexion tires operated at lower inflation pressures increase the tire-soil contact area, and when coupled with the appropriate tillage systems can reduce soil compaction. Crop rotation with deep-rooted and cover crops (e.g., creation of bio-drilling by the decomposition of roots) and conservation agriculture practices can play an important role in reducing soil compaction, which results in increased pore volume to support proper root development and access to nutrients. The current literature review summarized here will help to better understand the causes and effects of soil compaction arising from the use of heavy machinery, improper tire inflation pressure, and field trafficking on soil properties, crop growth and development, yield, and farm income. It will also assist in improved understanding of soil compaction and provide useful information to growers, ranchers, researchers, and policymakers to support better decisions on reducing the impact of soil compaction in production agriculture.

\section{Future Research Needs}

Mechanization is an integral part of modern and intensive agriculture. Additional research on reducing soil compaction, and ameliorating of compacted soils is needed to minimize soil and ecosystem disturbance and maximize crop productivity. Comprehensive research on compacted and uncompacted layers in the soil profile across different soil types and environments, both for shallow and deep-rooted crops, is required. Studies on new tires technologies with low and high inflation pressures for machinery of varying axle loads and suitable cultivation practices on, benefits to 


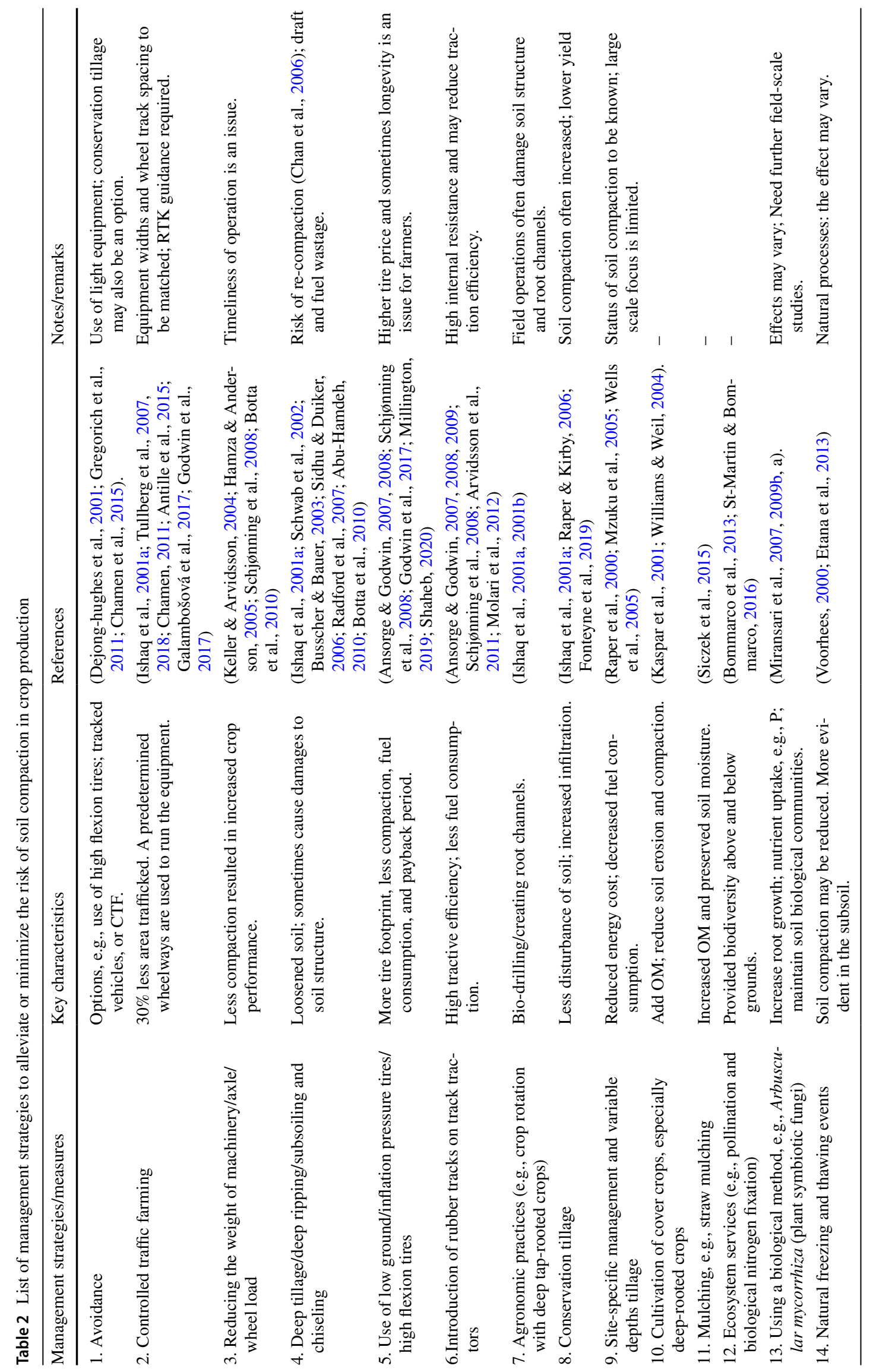


the ecosystem are urgently needed. Future research needs to focus on sensor development for measuring ingand quantifing the spatial and temporal distributions of soil compaction, and its management. Investigation of undisturbed and disturbed soil profiles using X-ray computed tomography tool could provide a detailed understanding of the effect of soil compaction and alteration of soil structure. With the advances in precision agriculture and application of remote sensing tools for compaction assessment and mapping; modeling of soil compactiona and management, and optimization of soil-machine-crop systems are warranted. Further research is needed to focus on developing crop varieties and hybrids with desired root characters that penetrate the soil, anchor the plant and access water and nutrients to support crop grow in compacted soils.

Authors' Contribution Conceptualization, Md Rayhan Shaheb (M.R.S.) and Scott A. Shearer (S.A.S.); writingoriginal draft preparation, M.R.S.; writing, review and editing, M.R.S., Ramarao Venkatesh (R.V.) and S.A.S.; visualization, M.R.S. and S.A.S.; supervision, S.A.S. All authors have read and agreed to the published version of the manuscript.

Acknowledgements The authors wish to acknowledge the salary and research support provided in part by state and federal funds appropriated to the Ohio Agricultural Research and Development Center and The Ohio State University.

\section{Declarations}

Conflict of Interest The authors declare that there is no conflict of interest.

Open Access This article is licensed under a Creative Commons Attribution 4.0 International License, which permits use, sharing, adaptation, distribution and reproduction in any medium or format, as long as you give appropriate credit to the original author(s) and the source, provide a link to the Creative Commons licence, and indicate if changes were made. The images or other third party material in this article are included in the article's Creative Commons licence, unless indicated otherwise in a credit line to the material. If material is not included in the article's Creative Commons licence and your intended use is not permitted by statutory regulation or exceeds the permitted use, you will need to obtain permission directly from the copyright holder. To view a copy of this licence, visit http://creativecommons.org/licenses/by/4.0/.

\section{References}

Aase, J. K., Bjorneberg, D. L., \& Sojka, R. E. (2001). Zone-subsoiling relationships to bulk density and cone index on a furrow-irrigated soil. Transactions of the ASAE, 44(3), 577-583. https://doi.org/ $10.13031 / 2013.6118$

Abu-Hamdeh, N. H., \& Al-Widyan, M. I. (2000). Effect of axle load, tire inflation pressure, and tillage system on soil physical properties and crop yield of a Jordanian soil. Transactions of the ASAE, 43(1), 13-21. https://doi.org/10.13031/2013.2677

Abu-Hamdeh, N. H. (2010). Compaction and subsoiling effects on corn growth and soil bulk density. Soil Science Society of America Journal, 67(4), 1213-1219. https://doi.org/10.2136/sssaj2003. 1213

Al-Kaisi, M., Licht, M., \& Tekeste, M. (2018). How to minimize soil compaction during harvest. Retrieved May 5, 2020, from https:// crops.extension.iastate.edu/cropnews/2018/10

Alakukku, L. (2000). Response of annual crops to subsoil compaction in a field experiment on clay soil lasting 17 years. Advances in Geoecology, 32, 205-208. Retrieved from https://www.cabdirect. org/cabdirect/abstract/20013087588

Alakukku, L., Weisskopf, P., Chamen, W. C. T., Tijink, F. G. J., van der Linden, J. P., Pires, S., et al. (2003). Prevention strategies for field traffic-induced subsoil compaction: A review: Part 1. Machine/ soil interactions. Soil and Tillage Research, 73(1), 145-160. https://doi.org/10.1016/S0167-1987(03)00107-7

Amato, M., \& Ritchie, J. T. (2002). Spatial distribution of roots and water uptake of maize (Zea mays L.) as affected by soil structure. Crop Science, 42, 773-780. https://doi.org/10.2135/crops ci2002.7730

Ansorge, D., \& Godwin, R. J. (2007). The effect of tyres and a rubber track at high axle loads on soil compaction, part 1: Single axlestudies. Biosystems Engineering, 98(1), 115-126. https://doi.org/ 10.1016/j.biosystemeng.2007.06.005

Ansorge, D., \& Godwin, R. J. (2008). The effect of tyres and a rubber track at high axle loads on soil compaction, part 2: Multi-axle machine studies. Biosystems Engineering, 99, 338-347. https:// doi.org/10.1016/j.biosystemseng.2007.11.014

Ansorge, D., \& Godwin, R. J. (2009). The effect of tyres and a rubber track at high axle loads on soil compaction: Part 3: Comparison of virgin compression line approaches. Biosystems Engineering, 104(2), 278-287. https://doi.org/10.1016/j.biosystemseng.2009. 06.024

Antille, D. L., Ansorge, D., Dresser, M. L., \& Godwin, R. J. (2013). Soil displacement and soil bulk density changes as affected by tire size. Transactions of the ASABE, 56(5), 1683-1693. https:// doi.org/10.13031/trans.56.9886

Antille, D. L., Chamen, T., \& Lal, R. (2015). The potential of controlled traffic farming to mitigate greenhouse gas emissions and enhance carbon sequestration in arable land: A critical review. Transactions of the ASABE, 58(3), 707-731. https://doi.org/10. 13031/trans.58.11049

Arvidsson, J., Westlin, H., Keller, T., \& Gilbertsson, M. (2011). Rubber track systems for conventional tractors - Effects on soil compaction and traction. Soil and Tillage Research, 117, 103-109. https://doi.org/10.1016/j.still.2011.09.004

Arvidsson, J., \& Keller, T. (2004). Soil precompression stress. Soil and Tillage Research, 77(1), 85-95. https://doi.org/10.1016/j. still.2004.01.003

Arvidsson, J., \& Keller, T. (2007). Soil stress as affected by wheel load and Tyre inflation pressure. Soil and Tillage Research, 96(1), 284-291. https://doi.org/10.1016/j.still.2007.06.012

ASABE Standards. (2013). ASAE EP542 FEB1999 (R2013). Procedures for using and reporting data obtained with the soil cone penetrometer. American Society of Agricultural and Biological Engineers (ASABE). St. Joseph, MI.

ASABE Standards. (2018). ASAE S313.3 Feb 1999 (R2018). Soil cone penetrometer. American Society of Agricultural and Biological Engineers (ASABE). St. Joseph, MI. Retrieved from https://elibr ary.asabe.org/pdfviewer.aspx?GUID=0D485B88-5E54-46E58296-C99F336B628D

Atkinson, B. S., Sparkes, D. L., \& Mooney, S. J. (2009). Effect of seedbed cultivation and soil macrostructure on the establishment 
of winter wheat (Triticum aestivum). Soil and Tillage Research, 103(2), 291-301. https://doi.org/10.1016/j.still.2008.10.027

Badalıkova, B. (2010). Influence of soil tillage on soil compaction. In A. Dedousis \& T. Bartzanas (Eds.), soil engineering (Vol. 20, pp. 19-30). Springer, Berlin, Heidelberg. doi: https://doi.org/10. 2136/sssaj1952.03615995001600030026x.

Batey, T. (2009). Soil compaction and soil management - A review. Soil Use and Management, 25(4), 335-345. https://doi.org/10. 1111/j.1475-2743.2009.00236.x

Battiato, A., Diserens, E., Laloui, L., \& Sartori, L. . (2013). A mechanistic approach to topsoil damage due to slip of tractor tires. Journal of Agricultural Science and Applications, 02(03), 160 168. https://doi.org/10.14511/jasa.2013.020305

Beckers, E., Plougonven, E., Roisin, C., Hapca, S., Léonard, A., \& Degré, A. (2014). X-ray microtomography: A porosity-based thresholding method to improve soil pore network characterization? Geoderma, 219-220, 145-154. https://doi.org/10.1016/j. geoderma.2014.01.004

Bengough, A. G., Bransby, M. F., Hans, J., McKenna, S. J., Roberts, T. J., \& Valentine, T. A. (2006). Root responses to soil physical conditions; growth dynamics from field to cell. Journal of Experimental Botany, 57(2), 437-447. https://doi.org/10.1093/ jxb/erj003

Berisso, F. E., Schjønning, P., Keller, T., Lamandé, M., Etana, A., de Jonge, L. W., et al. (2012). Persistent effects of subsoil compaction on pore size distribution and gas transport in a loamy soil. Soil and Tillage Research, 122, 42-51. https://doi.org/10.1016/J. still.2012.02.005

Berisso, F. E., Schjønning, P., Lamandé, M., Weisskopf, P., Stettler, M., \& Keller, T. (2013). Effects of the stress field induced by a running tire on the soil pore system. Soil and Tillage Research, 131, 36-46. https://doi.org/10.1016/j.still.2013.03.005

Bian, D., Jia, G., Cai, L., Ma, Z., Eneji, A. E., \& Cui, Y. (2016). Effects of tillage practices on root characteristics and root lodging resistance of maize. Field Crops Research, 185, 89-96. https://doi.org/ 10.1016/j.fcr.2015.10.008

Blanco-Canqui, H., Claassen, M. M., \& Stone, L. R. (2010). Controlled traffic impacts on physical and hydraulic properties in an intensively cropped no-till soil. Soil Science Society of America Journal, 74(6), 2142. https://doi.org/10.2136/sssaj2010.0061

Bommarco, R., Kleijn, D., \& Potts, S. G. (2013). Ecological intensification: Harnessing ecosystem services for food security. Trends in Ecology and Evolution, 28(4), 230-238. https://doi.org/10. 1016/j.tree.2012.10.012

Botta, G., Jorajuria, D., Balbuena, R., \& Rosatto, H. (2004). Mechanical and cropping behavior of direct drilled soil under different traffic intensities: Effect on soybean (Glycine max L.) yields. Soil and Tillage Research, 78(1), 53-58. https://doi.org/10.1016/j. still.2004.01.004

Botta, G. F., Rivero, D., Tourn, M., Melcon, F. B., Pozzolo, O., Nardon, G., et al. (2008). Soil compaction produced by tractor with radial and cross-ply tyres in two tillage regimes. Soil and Tillage Research, 101(1-2), 44-51. https://doi.org/10.1016/j.still.2008. 06.001

Botta, G. F., Tolon-Becerra, A., Lastra-Bravo, X., \& Tourn, M. (2010). Tillage and traffic effects (planters and tractors) on soil compaction and soybean (Glycine max L.) yields in Argentinean pampas. Soil and Tillage Research, 110(1), 167-174. https://doi.org/10. 1016/j.still.2010.07.001

Bouwman, L. A., \& Arts, W. B. M. (2000). Effects of soil compaction on the relationships between nematodes, grass production and soil physical properties. Applied Soil Ecology, 14(3), 213-222. https://doi.org/10.1016/S0929-1393(00)00055-X

Busscher, W. J., \& Bauer, P. J. (2003). Soil strength, cotton root growth and lint yield in a southeastern USA coastal loamy sand. Soil and
Tillage Research, 74(2), 151-159. https://doi.org/10.1016/j.still. 2003.06.002

Canillas, E. C., \& Salokhe, V. M. (2002). Modeling compaction in agricultural soils. Journal of Terramechanics, 39(2), 71-84. https:// doi.org/10.1016/S0022-4898(02)00007-1

Chamen, T. (2015). Controlled traffic farming - from worldwide research to adoption in Europe and its future prospects. Acta Technologica Agriculturae 3, 18(3), 64-73. https://doi.org/10. 1515/ata-2015-0014

Chamen, W. (2011). The effects of low and controlled traffic systems on soil physical properties, yields and the profitability of cereal crops on a range of soil types. Ph.D. thesis, Cranfield University, Cranfield, Bedford, United Kingdom. Retrieved from http:// dspace.lib.cranfield.ac.uk/handle/1826/7009

Chamen, W. C. T., Moxey, A. P., Towers, W., Balana, B., \& Hallett, P. D. (2015). Mitigating arable soil compaction: A review and analysis of available cost and benefit data. Soil and Tillage Research, 146, 10-25. https://doi.org/10.1016/j.still.2014.09.011

Chan, K. Y., Oates, A., Swan, A. D., Hayes, R., Dear, B. S., \& Peoples, M. B. (2006). Agronomic consequences of tractor wheel compaction on a clay soil. Soil and Tillage Research, 89(1), 13-21. https://doi.org/10.1016/j.still.2005.06.007

Chen, G., \& Weil, R. R. (2010). Penetration of cover crop roots through compacted soils. Plant and Soil, 331(1), 31-43. https://doi.org/ 10.1007/s11104-009-0223-7

Chen, G., Weil, R. R., \& Hill, R. L. (2014). Effects of compaction and cover crops on soil least limiting water range and air permeability. Soil and Tillage Research, 136, 61-69. https://doi.org/10. 1016/j.still.2013.09.004

Chyba, J., Kroulík, M., Krištof, K., Misiewicz, P. A., \& Chaney, K. (2014). Influence of soil compaction by farm machinery and livestock on water infiltration rate on grassland. Agronomy Research, 12(1), 59-64.

Clark, L. J., Whalley, W. R., \& Barraclough, P. B. (2003). How do roots penetrate strong soil? Plant and Soil, 255(1), 93-104. https://doi. org/10.1023/A:1026140122848

Colombi, T., Braun, S., Keller, T., \& Walter, A. (2017). Artificial macropores attract crop roots and enhance plant productivity on compacted soils. Science of the Total Environment, 574, 12831293. https://doi.org/10.1016/j.scitotenv.2016.07.194

Colombi, T., \& Keller, T. (2019). Developing strategies to recover crop productivity after soil compaction - A plant eco-physiological perspective. Soil \& Tillage Research, 191, 156-161. https://doi. org/10.1016/j.still.2019.04.008

Colombi, T., Torres, L. C., Walter, A., \& Keller, T. (2018). Feedbacks between soil penetration resistance, root architecture and water uptake limit water accessibility and crop growth - A vicious circle. Science of the Total Environment, 626, 1026-1035. https:// doi.org/10.1016/j.scitotenv.2018.01.129

Copas, M. E., Bussan, A. J., Drilias, M. J., \& Wolkowski, R. P. (2009). Potato yield and quality response to subsoil tillage and compaction. Agronomy Journal, 101(1), 82-90. https://doi.org/10.2134/ agronj2007.0031

Defossez, P., \& Richard, G. (2002). Models of soil compaction due to traffic and their evaluation. Soil and Tillage Research, 67(1), 41-64. https://doi.org/10.1016/S0167-1987(02)00030-2

Dejong-hughes, J., Monterief, W. B., Voorhees, W. B., \& Swan, J. B. (2001). Soil compaction: Causes, effects and control (FO3115-S). University of Minnesota Extension Service, St. Paula, MN. Retrieved from https://conservancy.umn.edu/handle/11299/ 55483

Dexter, A. R. (2004). Soil physical quality: Part I. theory, effects of soil texture, density, and organic matter, and effects on root growth. Geoderma, 120(3-4), 201-214. https://doi.org/10.1016/j.geode rma.2003.09.004 
Duiker, S. (2004a). Effects of soil compaction. doi: 10.1111/j.1469-7610.2008.02015.x.

Duiker, S. (2002). Diagnosing soil compaction using a penetrometer. Agronomy Facts, 63, 1-4.

Duiker, S. (2004b). Avoiding soil compaction. Retrieved March 4, 2019, from https://extension.psu.edu/avoiding-soil-compaction

Dyck, J. (2017). Soil compaction: Stay off the field until the soil is ready. Field crop news, published in 30 may 2017. Retrieved October 10, 2020, from https://fieldcropnews.com/2017/05/soilcompaction-stay-off-the-field-until-the-soil-is-ready/

ECIFM. (2017). Mechanisation and technology. Retrieved January 29, 2017, from http://www.ecifm.rdg.ac.uk/mehanisation_and_techn ology.htm

Eliasson, L. (2005). Effects of forwarder Tyre pressure on rut formation and soil compaction. Silva Fennica Monographs, 39(4), 549-557. https://doi.org/10.14214/sf.366

Etana, A., Larsbo, M., Keller, T., Arvidsson, J., Schjønning, P., Forkman, J., \& Jarvis, N. (2013). Persistent subsoil compaction and its effects on preferential flow patterns in a loamy till soil. Geoderma, 192, 430-436. https://doi.org/10.1016/j.geoderma.2012. 08.015

Fonteyne, S., Martinez Gamiño, M. A., Tejeda, A. S., \& Verhulst, N. (2019). Conservation agriculture improves long-term yield and soil quality in irrigated maize-oats rotation. Agronomy, 9(12), 1-13. https://doi.org/10.3390/agronomy9120845

Galambošová, J., Macák, M., Rataj, V., Antille, D. L., Godwin, R. J., Chamen, W. C. T., ... Chlpík, J. (2017). Field evaluation of controlled traffic farming in Central Europe using commercially available machinery. Transactions of the ASABE, 60(3), 657-669. https://doi.org/10.13031/trans.11833

Gan-mor, S., \& Clark, R. L. (2001). DGPS-based automatic guidance - Implementation and economical analysis. 2001 ASABE Annual International Meeting, July 30-August 1, 011192, 1-13. St. Joseph, MI. https://doi.org/10.13031/2013.4123

Gebauer, R., \& Martinková, M. (2005). Effects of pressure on the root systems of Norway spruce plants (Picea abies [L.] Karst.). Journal of Forest Science, 51(6), 268-275.https://doi.org/10. 17221/4563-JFS

Gelder, B. K., Cruse, R. M., \& Zhang, X. Y. (2007). Comparison of track and tire effects of planter tractors on corn yield and soil properties. Transactions of the ASAE, 50(2), 365-370. https:// doi.org/10.13031/2013.22627

Gerasimov, Y., \& Katarov, V. (2010). Effect of boogie track and slash reinforcement on sinkage and soil compaction in soft terrains. Croatian Journal of Forest Engineering, 31, 35-45. https:// hrcak.srce.hr/56926

Godwin, R. J., Misiewicz, P. A., Smith, E. K., Millington, W. A. Z., White, D. R., Dicken, E. T., \& Chaney, K. (2017). Summary of the effects of three tillage and three traffic systems on cereal yields over a four-year rotation. In 2017 ASABE Annual International Meeting, Spokane, 16-19 July, 1701652, 1-8. St. Joseph, MI. https://doi.org/10.13031/aim.201701652

Godwin, R. J., Misiewicz, P. A., White, D., Chamen, T., Galambošová, J., \& Stobart, R. (2015). Results from recent traffic systems research and the implications for future work. Acta Technologica Agriculturae, 18(3), 57-63. https://doi.org/ 10.1515/ata-2015-0013

Godwin, R., Misiewicz, P., White, D., Dickin, E., Grift, T., Pope, E., ... Dolowy, M. (2019). The effect of alternative traffic systems and tillage on soil condition, crop growth and production economics - extended abstract. In TAE 2019 - Proceeding of 7th International Conference on Trends in Agricultural Engineering, Prague, Czech Republic, September 17-20, 133-134.

Gregorich, E. G., Lapen, D. R., Ma, B. L., McLaughlin, N. B., \& VandenBygaart, A. J. (2011). Soil and crop response to varying levels of compaction, nitrogen fertilization, and clay content.
Soil Science Society of America Journal, 75(4), 1483-1492. https://doi.org/10.2136/sssaj2010.0395

Gregory, A. S., Ritz, K., Mcgrath, S. P., Quinton, J. N., Goulding, K. W. T., Jones, R. J. A., et al. (2015). A review of the impacts of degradation threats on soil properties in the UK. Soil Use and Management, 31(Suppl. 1), 1-15. https://doi.org/10.1111/ sum. 12212

Gruber, P. (2021, February 12). Wetter climate raises soil compaction risk. Retrieved February 22, 2021, from https://www.lanca sterfarming.com/news/main_edition/

Grzesiak, M. T. (2009). Impact of soil compaction on root architecture, leaf water status, gas exchange and growth of maize and triticale seedlings. Plant Root, 3, 10-16. https://doi.org/ 10.3117/plantroot.3.10

Grzesiak, S., Grzesiak, M. T., Hura, T., Marcińska, I., \& Rzepka, A. (2013). Changes in root system structure, leaf water potential and gas exchange of maize and triticale seedlings affected by soil compaction. Environmental and Experimental Botany, 88, 2-10. https://doi.org/10.1016/j.envexpbot.2012.01.010

Hakansson, I. (2005). Machinery induced compaction of arable soils. Incidence - consequences - countermeasures. (I. ha ${ }^{\circ} \mathrm{kansson}$, Ed.) (1st ed.). Uppsala: Swedish University of Agricultural Sciences Department of Soil Sciences.

Hakansson, I., \& Lipiec, J. (2000). A review of the usefulness of relative bulk density values in studies of soil structure and compaction. Soil and Tillage Research, 53(2), 71-85. https:// doi.org/10.1016/S0167-1987(99)00095-1

Hallett, P., Balana, B., Towers, W., Moxey, A., \& Chamen, T. (2012). Studies to inform policy development with regard to soil degradation. Subproject A : Cost curve for mitigation of soil compaction. Defra SP1305 ( CTE 1024 ).

Hamza, M. A., Al-Adawi, S. S., \& Al-Hinai, K. A. (2011). Effect of combined soil water and external load on soil compaction. Soil Research, 49(2), 135-142. https://doi.org/10.1071/sr09144

Hamza, M. A., \& Anderson, W. K. (2005). Soil compaction in cropping systems: A review of the nature, causes and possible solutions. Soil and Tillage Research, 82(2), 121-145. https://doi.org/10. 1016/j.still.2004.08.009

Han, S. K., Han, H. S., Page-Dumroese, D. S., \& Johnson, L. R. (2009). Soil compaction associated with cut-to-length and whole-tree harvesting of a coniferous forest. Canadian Journal of Forest Research, 39, 976-989. https://doi.org/10.1139/X09-027

Hassan, F. U., Ahmad, M., Ahmad, N., \& Abbasi, M. K. (2007). Effects of subsoil compaction on yield and yield attributes of wheat in the sub-humid region of Pakistan. Soil and Tillage Research, 96(1-2), 361-366. https://doi.org/10.1016/j.still.2007.06.005

Hatley, D., Wiltshire, J., Basford, B., Royale, S., Buckley, D., \& Johnson, P. (2005). Soil compaction and potato crops. Research review (Vol. R260). Oxford, UK. Retrieved from http://www. potatoes.ahdb.org.uk/sites/default/files/publication_upload/R260 ADAS soil compaction review.Pdf.

Hoad, S. P., Russell, G., Lucas, M. E., \& Bingham, I. J. (2001). The management of wheat, barley, and oat root systems. Advances in Agronomy, 74, 193-246. https://doi.org/10.1016/S0065-2113(01) 74034-5

Hoeft, R. G., Nafziger, E. D., Johnson, R. R., \& Aldrich, S. R. (2000). Modern corn and soybean production. Champaign, IL: MCSP publications. (1st ed.). Champaign, IL.

Horn, R., Way, T., \& Rostek, J. (2003). Effect of repeated tractor wheeling on stress/strain properties and consequences on physical properties in structured arable soils. Soil and Tillage Research, 73(1-2), 101-106. https://doi.org/10.1016/S0167-1987(03) 00103-X

Horn, R., \& Fleige, H. (2003). A method for assessing the impact of load on mechanical stability and on physical properties of soils. 
Soil and Tillage Research, 73(1-2), 89-99. https://doi.org/10. 1016/S0167-1987(03)00102-8

Horn, R., Holthusen, D., Dörner, J., Mordhorst, A., Fleige, H., Nutrition, P., et al. (2019). Scale-dependent soil strengthening processes - What do we need to know and where to head for a sustainable environment? Soil \& Tillage Research, 195, 104388. https://doi.org/10.1016/j.still.2019.104388

Houšková, B., \& Montanarella, L. (2008). The natural susceptibility of European soils to compaction. In T. Gergely, L. Montanarella, \& E. Rusco (Eds.), Threats to soil quality in Europe (pp. 23-36). Luxmbourg: European Commission Joint Research Centre Institute for Environment and Sustainability. Retrieved from https:// esdac.jrc.ec.europa.eu/ESDB_Archive/eusoils_docs/other/eur23 438.pdf

Huber, S., Prokop, G., Arrouays, D., Banko, G., Bispo, A., Jones, R. J. ., ... Jones, A. . (2008). Environmental assessment of soil for monitoring volume I: Indicators \& criteria. (S. Huber, G. Prokop, D. Arrouays, G. Banko, A. Bispo, R. J. A. Jones, ... A. R. Jones, Eds.), environmental assessment of soil for monitoring volume I: Indicators \& criteria. Luxembourg: Office for Official Publications of the European Communities. https://doi.org/10. 2788/93515

Hula, J., Kroulik, M., \& Kovaricek, P. (2009). Effect of repeated passes over the soil on degree of soil compaction, (ČZU, in GPS autopiloty v zemědělstvi. CULS Prague), 39-44.

Ishaq, M., Hassan, A., Saeed, M., Ibrahim, M., \& Lal, R. (2001a). Subsoil compaction effects on crops in Punjab, Pakistan: I. soil physical properties and crop yield. Soil and Tillage Research, 59(1-2), 57-65. https://doi.org/10.1016/S0167-1987(00)00189-6

Ishaq, M., Ibrahim, M., Hassan, A., Saeed, M., \& Lal, R. (2001b). Subsoil compaction effects on crops in Punjab, Pakistan: II. Root growth and nutrient uptake of wheat and sorghum. Soil and Tillage Research, 60(3-4), 153-161. https://doi.org/10.1016/S01671987(01)00177-5

Ji, B., Zhao, Y., Mu, X., Liu, K., \& Li, C. (2013). Effects of tillage on soil physical properties and root growth of maize in loam and clay in Central China. Plant, Soil, \& Environment, 59(7), 295-302. https://doi.org/10.17221/57/2013-pse

Jin, K., Shen, J., Ashton, R. W., White, R. P., Dodd, I. C., Phillips, A. L., et al. (2015). The effect of impedance to root growth on plant architecture in wheat. Plant and Soil, 392(1-2), 323-332. https:// doi.org/10.1007/s11104-015-2462-0

Jones, R. J. A., Spoor, G., \& Thomasson, A. J. (2003). Vulnerability of subsoils in Europe to compaction: a preliminary analysis. Soil and Tillage Research, 73(1-2), 131-143. https://doi.org/10.1016/ S0167-1987(03)00106-5

Kaspar, T. C., Radke, J. K., \& Laflen, J. M. (2001). Small grain cover crops and infiltration, runoff, and wheel traffic effects on infiltration, runoff, and erosion. Journal of Soil and Water Conservation, 56(2), 160-164. Retrieved from https://www.jswconline. org/content $/ 56 / 2 / 160$

Keller, T., \& Arvidsson, J. (2004). Technical solutions to reduce the risk of subsoil compaction: Effects of dual wheels, tandem wheels and Tyre inflation pressure on stress propagation in soil. Soil and Tillage Research, 79(2), 191-205. https://doi.org/10. 1016/j.still.2004.07.008

Keller, T.. (2004). Soil compaction and soil tillage - Studies in agricultural soil mechanics. Doctoral dissertation. Swedish University of Agricultural Sciences, Uppsala. Sweden.

Keller, T., Sandin, M., Colombi, T., Horn, R., \& Or, D. (2019). Historical increase in agricultural machinery weights enhanced soil stress levels and adversely affected soil functioning. Soil \& Tillage Research, 194(May), 104293. https://doi.org/10.1016/j.still. 2019.104293

Khanal, S., Kc, K., Fulton, J. P., Shearer, S., \& Ozkan, E. (2020). Remote sensing in agriculture - accomplishments, limitations
, and opportunities. Remote Sensing, 12(3783), 2-29. https://doi. org/10.3390/rs12223783

Kirby, M. (2007). Whither soil compaction research? Letter to the editor. Soil and Tillage Research, 93(2), 472-475. https://doi.org/ 10.1016/j.still.2006.04.008

Klopfenstein, A. A. (2016). An empirical model for estimating corn yield loss from compaction events with tires vs. tracks high axle loads. Master's Thesis. The Ohio State University, Columbus, $\mathrm{OH}$, USA.

Koolen, A. J., \& Kuipers, H. (1983). Agricultural soil mechanics. Advanced series in agricultural sciences 13. (D. F. R. Bommer, B. R. Sabey, G. W. Thomas, Y. Vaadia, \& L. D. van Vleck, Eds.). Springer-Verlag. doi: 10.1210/jc.2003-030459.

Kroulík, M., Kvíz, Z., Kumhála, F., Hůla, J., \& Loch, T. (2011). Procedures of soil farming allowing reduction of compaction. Precision Agriculture, 12(3), 317-333. https://doi.org/10.1007/ s11119-010-9206-1

Kroulík, M., Kumhála, F., Hůla, J., \& Honzík, I. (2009). The evaluation of agricultural machines field trafficking intensity for different soil tillage technologies. Soil and Tillage Research, 105(1), 171-175. https://doi.org/10.1016/j.still.2009.07.004

Kroulík, M., Hůla, J., Šindelár̆, R., \& Illek, F. (2007). Water infiltration into soil related to the soil tillage intensity. Soil and Water Research, 2(1), 15-24.

Kulkarni, S. G., Bajwa, S. G., \& Huitink, G. (2010). Investigation of the effects of soil compaction in cotton. Transactions of the ASABE, 53(3), 667-674. https://doi.org/10.13031/2013.30058

Lamandé, M., \& Schjønning, P. (2010). Transmission of vertical stress in a real soil profile. Part II: Effect of Tyre size, inflation pressure and wheel load. Soil \& Tillage Research, 114, 71-77. https://doi. org/10.1016/j.still.2010.08.011

Lamandé, M., \& Schjønning, P. (2018). Soil mechanical stresses in high wheel load agricultural field traffic: A case study. Soil Research. https://doi.org/10.1071/SR17117

Li, Y., Tullberg, J. N., \& Freebairn, D. M. (2001). Traffic and residue cover effects on infiltration. Australian Journal of Soil Research, 39(2), 239-247. Retrieved from http://www.publish.csiro.au/sr/ SR00017

Lipiec, J., \& Hatano, R. (2003). Quantification of compaction effects on soil physical properties and crop growth. Geoderma, 116(1), 107-136. https://doi.org/10.1016/S0016-7061(03)00097-1

Lipiec, J., Arvidsson, J., \& Murer, E. (2003a). Review of modelling crop growth, movement of water and chemicals in relation to topsoil and subsoil compaction. Soil \& Tillage Research, 73(1-2), 15-29. https://doi.org/10.1016/S0167-1987(03)00096-5

Lipiec, J., Medvedev, V. V., Birkas, M., Dumitru, E., Lyndina, T. E., Rousseva, S., \& Fulajtár, E. (2003b). Effect of soil compaction on root growth and crop yield in central and Eastern Europe. International Agrophysics, 17, 61-69.

Lipiec, J., Horn, R., Pietrusiewicz, J., \& Siczek, A. (2012). Effects of soil compaction on root elongation and anatomy of different cereal plant species. Soil and Tillage Research, 121, 74-81. https://doi.org/10.1016/j.still.2012.01.013

McKenzie, R. (2010). Agricultural soil compaction: Causes and management. Retrieved January 10, 2019, from www. agriculture. alberta.ca

Millington, W. A. J. (2019). The effect of low ground pressure and controlled traffic farming systems on soil properties and crop development for three tillage systems. Ph.D. thesis. Harper Adams University, Newport, Shropshire, United Kingdom.

Millington, W. A. J., Misiewicz, P. A., Dickin, E. T., White, D. R., \& Godwin, R. J. (2016). An investigation into the effect of soil compaction and tillage on plant growth and yield of winter barley (Hordeum vulgare L.). In 2016 ASABE Annual International Meeting, Orlando, 17-20 July, 1901979, 1-12, St. Joseph, MI. https://doi.org/10.13031/aim.20162461725 
Miransari, M., Bahrami, H. A., Rejali, F., \& Malakouti, M. J. (2009a). Effects of arbuscular mycorrhiza, soil sterilization, and soil compaction on wheat (Triticum aestivum L.) nutrients uptake. Soil and Tillage Research, 104(1), 48-55. https://doi.org/10.1016/j. still.2008.11.006

Miransari, M., Bahrami, H. A., Rejali, F., \& Malakouti, M. J. (2009b). Effects of soil compaction and arbuscular mycorrhiza on corn (Zea mays L.) nutrient uptake. Soil and Tillage Research, 103(2), 282-290. https://doi.org/10.1016/j.still.2008.10.015

Miransari, M., Bahrami, H. A., Rejali, F., Malakouti, M. J., \& Torabi, H. (2007). Using arbuscular mycorrhiza to reduce the stressful effects of soil compaction on corn (Zea mays L.) growth. Soil Biology and Biochemistry, 39(8), 2014-2026. https://doi.org/10. 1016/j.soilbio.2007.02.017

Misiewicz, P. A. (2010). The evaluation of the soil pressure distribution and carcass stiffness resulting from pneumatic agricultural tires. Ph.D. thesis. Cranfield University, Cranfield, Bedford, United Kingdom.

Molari, G., Bellentani, L., Guarnieri, A., Walker, M., \& Sedoni, E. (2012). Performance of an agricultural tractor fitted with rubber tracks. Biosystems Engineering, 111(1), 57-63. https://doi.org/ 10.1016/j.biosystemseng.2011.10.008

Mooney, S. J. (2006). Three-dimensional visualization and quantification of soil macroporosity and water flow patterns using computed tomography. Soil Use and Management, 18(2), 142-151. https://doi.org/10.1111/j.1475-2743.2002.tb00232.x

Munkholm, L. J., Heck, R. J., \& Deen, B. (2013). Long-term rotation and tillage effects on soil structure and crop yield. Soil and Tillage Research, 127, 85-91. https://doi.org/10.1016/j.still.2012. 02.007

Mzuku, M., Khosla, R., Reich, R., Inman, D., Smith, F., \& MacDonald, L. (2005). Spatial variability of measured soil properties across site-specific management zones. Soil Science Society of America Journal, 69(5), 1572-1579. https://doi.org/10.2136/sssaj2005. 0062

Nawaz, M. F., Bourrié, G., \& Trolard, F. (2013). Soil compaction impact and modeling. A review. Agronomy for Sustainable Development, 33(2), 291-309. https://doi.org/10.1007/ s13593-011-0071-8

Nix, J. (2011). Farm management pocketbook (42nd ed.). Melton Mowbray Leicestershire

Nosalewicz, A., \& Lipiec, J. (2014). The effect of compacted soil layers on vertical root distribution and water uptake by wheat. Plant and Soil, 375(1-2), 229-240. https://doi.org/10.1007/ s11104-013-1961-0

Obour, P. B., Schjønning, P., \& Peng, Y. (2017). Subsoil compaction assessed by visual evaluation and laboratory methods. Soil and Tillage Research, 173, 4-14. https://doi.org/10.1016/j.still.2016. 08.015

Oldeman, L. R. (1992). Global extent of soil degradation. Published in ISRIC bi-annual report 1991-1992. Wageningen, The Netherlands. Retrieved from http://edepot.wur.nl/299739

Passioura, J. B. (2002). Soil conditions and plant growth. Plant, Cell and Environment, 25(2), 311-318. https://doi.org/10.1046/j. 0016-8025.2001.00802.x

Pires, L. F., Auler, A. C., Roque, W. L., \& Mooney, S. J. (2020). X-ray microtomography analysis of soil pore structure dynamics under wetting and drying cycles. Geoderma, 362(January), 114103. https://doi.org/10.1016/j.geoderma.2019.114103

Pitla, S. K., Luck, J. D., Werner, J., Lin, N., \& Shearer, S. A. (2016). In-field fuel use and load states of agricultural field machinery. Computers and Electronics in Agriculture, 121, 290-300. https:// doi.org/10.1016/j.compag.2015.12.023

Pulido-Moncada, M., Munkholm, L. J., \& Schjønning, P. (2019). Wheel load, repeated wheeling, and traction effects on subsoil compaction in northern Europe. Soil and Tillage Research, 186, 300-309. https://doi.org/10.1016/j.still.2018.11.005

Rab, M. A., Haling, R. E., Aarons, S. R., Hannah, M., Young, I. M., \& Gibson, D. (2014). Evaluation of X-ray computed tomography for quantifying macroporosity of loamy pasture soils. Geoderma, 213, 460-470. https://doi.org/10.1016/j.geoderma.2013.08.037

Rachman, A., Anderson, S. H., \& Gantzer, C. J. (2005). Computedtomographic measurement of soil macroporosity parameters as affected by stiff-stemmed grass hedges. Soil Science Society of America Journal, 69(5), 1609-1616. https://doi.org/10.2136/ sssaj2004.0312

Radford, B. J., Yule, D. F., McGarry, D., \& Playford, C. (2007). Amelioration of soil compaction can take 5 years on a vertisol under no till in the semi-arid subtropics. Soil and Tillage Research, 97(2), 249-255. https://doi.org/10.1016/j.still.2006.01.005

Raghavan, G. S. V., McKyes, E., Taylor, F., Richard, P., \& Watson, A. (1979). Vehicular traffic effects on development and yield of corn (maize). Journal of Terramechanics, 16(2), 69-76. https:// doi.org/10.1016/0022-4898(79)90002-8

Raper, R. L., Reeves, D. W., Burmester, C. H., \& Schwab, E. B. (2000). Tillage depth, tillage timing, and cover crop effects on cotton yield, soil strength, and tillage energy requirements. Applied Engineering in Agriculture, 16(4), 379-385. doi: $10.13031 / 2013.5363$

Raper, R. L. (2005). Agricultural traffic impacts on soil. Journal of Terramechanics, 42(3-4), 259-280. https://doi.org/10.1016/j. jterra.2004.10.010

Raper, R. L., \& Kirby, J. M. (2006). Soil compaction: How to do it, undo it, or avoid doing it. Agricultural Equipment Technology Conference, 913, 1-15.

Reichert, J. M., Suzuki, L. E. A. S., Reinert, D. J., Horn, R., \& Hakansson, I. (2009). Reference bulk density and critical degree-ofcompactness for no-till crop production in subtropical highly weathered soils. Soil \& Tillage Research, 102, 242-254. https:// doi.org/10.1016/j.still.2008.07.002

Rickson, R. J., Deeks, L. K., Corstanje, R., Newell-Price, P., Kibblewhite, M. G., Chambers, B., ... Waine, T. (2012). Indicators of soil quality - Physical properties (SP1611). Final report to DEFRA. Cranfield University and ADAS, UK. Final report to DEFRA. Cranfield University. Cranfield, UK, 1-45. http://randd. defra.gov.uk. Retrieved from http://randd.defra.gov.uk/Default. aspx ?Module $=$ More $\&$ Location $=$ None $\&$ ProjectID $=17595$.

Ripley, B. S., Gilbert, M. E., Ibrahim, D. G., \& Osborne, C. P. (2007). Drought constraints on $\mathrm{C} 4$ photosynthesis: Stomatal and metabolic limitations in $\mathrm{C} 3$ and $\mathrm{C} 4$ subspecies of Alloteropsis semialata. Journal of Experimental Botany, 58(6), 1351-1363. https:// doi.org/10.1093/jxb/erl302

Rosolem, C., Foloni, J. S., \& Tiritan, C. (2002). Root growth and nutrient accumulation in cover crops as affected by soil compaction. Soil and Tillage Research, 65(1), 109-115. https://doi.org/10. 1016/S0167-1987(01)00286-0

Ruser, R., Flessa, H., Russow, R., Schmidt, G., Buegger, F., \& Munch, J. C. (2006). Emission of $\mathrm{N}_{2} \mathrm{O}, \mathrm{N}_{2}$ and $\mathrm{CO}_{2}$ from soil fertilized with nitrate: Effect of compaction, soil moisture and rewetting. Soil Biology and Biochemistry, 38(2), 263-274. https://doi.org/ 10.1016/j.soilbio.2005.05.005

Sadras, V. O., Villalobos, F. J., \& Fereres, F. (2016). Crop development and growth. In F. Villalobos \& E. Fereres (Eds.), Principles of agronomy for sustainable agriculture (pp. 141-158). Springer. https://doi.org/10.1007/978-3-319-46116-8_11

Sakai, H., Nordfjell, T., Suadicani, K., Talbot, B., \& Bøllehuus, E. (2008). Soil compaction on forest soils from different kinds of tires and tracks and possibility of accurate estimate. Croatian Journal of Forest Engineering, 29(1), 15-27. https://hrcak.srce. $\mathrm{hr} / 25708$ 
Salokhe, V. M., \& Ninh, N. T. (1993). Modelling soil compaction under pneumatic tyres in clay soil. Journal of Terramechanics, 30(2), 63-75. https://doi.org/10.1016/0022-4898(93)90020-X

Schafer, R. L., Johnson, C. E., Koolen, A. J., Gupta, S. C., \& Horn, R. (1992). Future research needs in soil compaction. Transaction of the ASAE, 35(6), 1761-1770. https://doi.org/10.13031/ 2013.28795

Schjønning, P., Lamandé, M., Berisso, F. E., Simojoki, A., Alakukku, L., \& Andreasen, R. R. (2013). Gas diffusion, non-darcy air permeability, and computed tomography images of a clay subsoil affected by compaction. Soil Science Society of America Journal, 77(6), 1977. https://doi.org/10.2136/sssaj2013.06.0224

Schjønning, P., Lamandé, M., Tøgersen, F. A., Arvidsson, J., \& Keller, T. (2008). Modelling effects of Tyre inflation pressure on the stress distribution near the soil-Tyre interface. Biosystems Engineering, 99(1), 119-133. https://doi.org/10.1016/j.biosy stemseng.2007.08.005

Schwab, E. B., Reeves, D. W., Burmester, C. H., \& Raper, R. L. (2002). Conservation tillage systems for cotton in the Tennessee Valley. Soil Science Society of America Journal, 66(2), 569-577. https:// doi.org/10.2136/sssaj2002.5690

Scott, D. I., Tams, A. R., Berry, P. M., \& Mooney, S. J. (2005). The effects of wheel-induced soil compaction on anchorage strength and resistance to root lodging of winter barley (Hordeum vulgare L.). Soil and Tillage Research, 82(2), 147-160. https://doi.org/ 10.1016/j.still.2004.06.008

Shah, A. N., Tanveer, M., Rehman, A. U., Anjum, S. A., Iqbal, J., \& Ahmad, R. (2017a). Lodging stress in cereal-Effects and management: An overview. Environmental Science and Pollution Research, 24(6), 5222-5237. https://doi.org/10.1007/ s11356-016-8237-1

Shah, A. N., Tanveer, M., Shahzad, B., Yang, G., Fahad, S., Ali, S., et al. (2017b). Soil compaction effects on soil health and cropproductivity: An overview. Environmental Science and Pollution Research, 24(11), 10056-10067. https://doi.org/10.1007/ s11356-017-8421-y

Shaheb, M. R. (2020). A study on the effect of tyre inflation pressure on soil properties, growth and yield of maize and soybean in Central Illinois. Ph.D. thesis. Harper Adams University, Newport, Shropshire, United Kingdom.

Shaheb, M.R., Grift, T. E., Godwin, R. J., Dickin, E., White, D. R., \& Misiewicz, P. A. (2018). Effect of tire inflation pressure on soil properties and yield in a corn - soybean rotation for three tillage systems in the Midwestern United States. In 2018 ASABE Annual International Meeting, Detroit, 29 July-01 August, 1801834, 1-14. St. Joseph, MI. https://doi.org/10.13031/aim.201801834

Shaheb, Md Rayhan, Klopfenstein, A., Tietje, R. W., Wiegman, C. R., Dio, C. Di, Scarfagna, A., ... Shearer, S. A. (2021). Evaluation of soil-tire interface pressure distributions and areas resulting from various tire and track technologies and configurations. In 2021 ASABE Annual International Meeting, 12-16 July, 1-11. St. Joseph, MI. https://doi.org/10.13031/aim.202100889

Shaheb, Md Rayhan, Misiewicz, P. A., Godwin, R. J., Dickin, E., White, D. R., Mooney, S., ... Grift, T. E. (2020). A quantification of soil porosity using X-ray computed tomography of a Drummer silty clay loam soi. In 2020 ASABE Annual International Meeting, 12-15 July, 2000875, 1-13. St. Joseph, MI. https://doi.org/ 10.13031/aim.2000875

Siczek, A., Horn, R., Lipiec, J., Usowicz, B., \& Łukowski, M. (2015). Effects of soil deformation and surface mulching on soil physical properties and soybean response related to weather conditions. Soil and Tillage Research, 153, 175-184. https://doi.org/ 10.1016/j.still.2015.06.006

Sidhu, D., \& Duiker, S. W. (2006). Soil compaction in conservation tillage: Crop impacts. Agronomy Journal, 98(5), 1257-1264. https:// doi.org/10.2134/agronj2006.0070
Sivarajan, S., Maharlooei, M., Bajwa, S. G., \& Nowatzki, J. (2018). Impact of soil compaction due to wheel traffic on corn and soybean growth, development and yield. Soil and Tillage Research, 175, 234-243. https://doi.org/10.1016/j.still.2017.09.001

Smith, E. K., Misiewicz, P. A., Chaney, K., White, D. R., \& Godwin, R. J. (2014a). Effect of tracks and tires on soil physical properties in a sandy loam soil. In $2014 A S A B E$ and $C S B E / S C G A B$ Annual International Meeting, Montreal, Canada, July 13-16, 141912659, 1-7. St. Joseph, MI.

Smith, E. K., Misiewicz, P. A., Girardello, V., Arslan, S., Chaney, K., White, D. R., \& Godwin, R. J. (2014b). Effects of traffic and tillage on crop yield (winter wheat Triticum aestivum) and the physical properties of a sandy loam soil. In 2014 ASABE and CSBE/SCGAB Annual International Meeting, Montreal, Canada, July 13-16, 141912652, 1-14. St. Joseph, MI. Retrieved from http://www.scopus.com/inward/record.url?eid=2-s2.0-84911 476721\&partnerID $=$ tZOtx3y 1

Soane, G. C., Godwin, R. J., \& Spoor, G. (1986). Influence of deep loosening techniques and subsequent wheel traffic on soil structure. Soil and Tillage Research, 8, 231-237. https://doi.org/10. 1016/0167-1987(86)90336-3

Soane, G., Godwin, R., Marks, M., \& Spoor, G. (1987). Crop and soil response to subsoil loosening, deep incorporation of phosphorus and potassium fertilizer and subsequent soil management on a range of soil types.: Part 1: Response of arable crops. Soil Use and Management, 3(3), 123-130. https://doi.org/10.1111/j.14752743.1987.tb00720.x

Soehne, W. (1958). Fundamentals of pressure distribution and soil compaction under tractor tires. Agricultural Engineering, 39(5), 276-290.

Spoor, G., Tijink, F. G. J., \& Weisskopf, P. (2003). Subsoil compaction: Risk, avoidance, identification and alleviation. Soil and Tillage Research, 73(1-2), 175-182. doi: https://doi.org/10.1016/S01671987(03)00109-0.

SSSA. (2008). Glossary of soil science terms 2008. In Soil science Society of America Journal, 1-82. Madison, Wisconsin: Soil Science Society of America. Retrieved from https://www.soils.org

St-Martin, A., \& Bommarco, R. (2016). Soil compaction and insect pollination modify impacts of crop rotation on nitrogen fixation and yield. Basic and Applied Ecology, 17(7), 617-626. https:// doi.org/10.1016/j.baae.2016.07.001

Stalham, M. A., \& Allen, E. J. (2001). Effect of variety, irrigation regime and planting date on depth, rate, duration and density of root growth in the potato (Solanum tuberosum) crop. The Journal of Agricultural Science, 137, 251-270. https://doi.org/10.1017/ S0021859601001332

Stranks, S. N. (2006). The effects of Tyre systems on the depth and severity of compaction. MSc. Thesis, Cranfield University, Cranfield, Bedford, United Kingdom.

Sudibyo, A. (2011). Soil compaction, 1-29. Retrieved from ftp://ftp. fao.org/agl/emailconf/soilmoisture/docs/Soil_compaction_DEF. pdf

Sui-Kwong, Y., Nimah, M., \& Farran, M. (2011). Early sowing and irrigation to increase barley yields and water use efficiency in Mediterranean conditions. Agricultural Water Management, 98(12), 1776-1781. https://doi.org/10.1016/j.agwat.2011.07.009

Sweeney, D. W., Kirkham, M. B., \& Sisson, J. B. (2006). Crop and soil response to wheel-track compaction of a claypan soil. Agronomy Journal, 98(3), 637-643. https://doi.org/10.2134/agronj2005. 0254

Taina, I. A., Heck, R. J., \& Elliot, T. R. (2008). Application of X-ray computed tomography to soil science: A literature review. Canadian Journal of Soil Science, 88, 1-20. https://doi.org/10.4141/ cjss06027

Tolon-Becerra, A., Tourn, M., Botta, G. F., \& Lastra-Bravo, X. (2011). Effects of different tillage regimes on soil compaction, maize 
(Zea mays L.) seedling emergence and yields in the eastern Argentinean pampas region. Soil and Tillage Research, 117, 184-190. https://doi.org/10.1016/j.still.2011.10.003

Towers, W., I.C. Grieve, Hudson, G., Campbell, C. D., A.Lilly, Davidson, D. A., ... Hopkins, D. A. (2006). Scotland's soil resource - Current state and threats. Scottish Executive Environment and Rural Affairs Department, Environmental Research Report. Edinburgh. Retrieved from https://www2.gov.scot/Resource/Doc/ 149337/0039742.pdf

Tracy, S. R., Black, C. R., Roberts, J. A., McNeill, A., Davidson, R., Tester, M., et al. (2012a). Quantifying the effect of soil compaction on three varieties of wheat (Triticum aestivum L.) using X-ray micro-computed tomography. Plant and Soil, 353(1-2), 195-208. https://doi.org/10.1007/s11104-011-1022-5

Tracy, S. R., Black, C. R., Roberts, J. A., Sturrock, C., Mairhofer, S., Craigon, J., \& Mooney, S. J. (2012b). Quantifying the impact of soil compaction on root system architecture in tomato (Solanum lycopersicum) by X-ray micro-computed tomography. Annals of Botany, 110(2), 511-519. https://doi.org/10.1093/aob/mcs031

Trautner, A., \& Arvidsson, J. (2003). Subsoil compaction caused by machinery traffic on a Swedish Eutric Cambisol at different soil water contents. Soil and Tillage Research, 73(1-2), 107-118. https://doi.org/10.1016/S0167-1987(03)00104-1

Trükmann, K., Reintam, E., Kuht, J., Nugis, E., \& Edesi, L. (2008). Effect of soil compaction on growth of narrow-leafed lupine , oilseed rape and spring barley on sandy loam soil. Agronomy Research, 6(1), 101-108. Retrieved from http://www.eau.ee/ $\sim$ agronomy/vol061/p6110.pdf

Tubeileh, A., Groleau-Renaud, V., Plantureux, S., \& Guckert, A. (2003). Effect of soil compaction on photosynthesis and carbon partitioning within a maize-soil system. Soil and Tillage Research, 71(2), 151-161. https://doi.org/10.1016/S01671987(03)00061-8

Tullberg, J., Antille, D. L., Bluett, C., Eberhard, J., \& Scheer, C. (2018). Controlled traffic farming effects on soil emissions of nitrous oxide and methane. Soil and Tillage Research, 176, 18-25. https://doi.org/10.1016/j.still.2017.09.014

Tullberg, J. N. (2000). Wheel traffic effects on tillage draught. Journal of Agricultural Engineering Research, 75(4), 375-382. https:// doi.org/10.1006/jaer.1999.0516

Tullberg, J. N., Yule, D. F., \& McGarry, D. (2007). Controlled traffic farming-from research to adoption in Australia. Soil and Tillage Research, 97(2), 272-281. https://doi.org/10.1016/j.still.2007. 09.007
Van den Akker, J. J. H. (2006). Evaluation of soil physical quality of Dutch subsoils in two databases with some threshold values. In R. Horn, H. Fleige, S. Peth, \& X. Peng (Eds.), Soil management for sustainability, Advances in GeoEcology, 38, 490-497. Reiskirchen, Germany: Catena Verlag. Retrieved from https:// research.wur.nl/en/publications/evaluation-of-soil-physical-quali ty-of-dutch-subsoils-in-two-data

Van den Akker, J. J. H., Arvidsson, J., \& Horn, R. (2003). Introduction to the special issue on experiences with the impact and prevention of subsoil compaction in the European Union. Soil and Tillage Research, 73, 1-8. https://doi.org/10.1016/S0167-1987(03) 00094-1.

Van den Akker, J. J. H., \& Soane, B. (2004). Compaction. In D. Hillel (Ed.), Encyclopedia of soils in the environment (pp. 285-293).

Voorhees, W. B. (2000). Long-term effects of subsoil compaction on yield of maize. Advances in GeoEcology, 32, 331-338. Retrieved from https://www.cabdirect.org/cabdirect/abstract/20013087603

Wells, L. G., Stombaugh, T. S., \& Shearer, S. A. (2005). Crop yield response to precision deep tillage. Transaction of the ASAE, 48(3), 895-901. https://doi.org/10.13031/2013.18493

Whitmore, A. P., Whalley, W. R., Bird, N. R. A., Watts, C. W., \& Gregory, A. S. (2011). Estimating soil strength in the rooting zone of wheat. Plant and Soil, 339(1), 363-375. https://doi.org/ 10.1007/s11104-010-0588-7

Williams, S. M., \& Weil, R. R. (2004). Crop cover root channels may alleviate soil compaction effects on soybean crop. Soil Science Society of America Journal, 68(4), 1403. https://doi.org/10.2136/ sssaj2004.1403

Wolkoski, R., \& Lowery, B. (2008). Soil compaction: Causes, concerns, and cures. University of Wisconsin-Extension, Cooperative Extension, A3367 Retrieved from http://www.soils.wisc.edu/ extension/pubs/A3367.pdf

Wu, X., Tang, Y., Li, C., McHugh, A. D., Li, Z., \& Wu, C. (2018). Individual and combined effects of soil waterlogging and compaction on physiological characteristics of wheat in southwestern China. Field Crops Research, 215, 163-172. https://doi.org/10. 1016/J.FCR.2017.10.016

Zhang, W., Ricketts, T. H., Kremen, C., \& Carney, K. (2007). Ecosystem services and dis-services to agriculture. Ecological Economics, 64(2), 253-260. https://doi.org/10.1016/j.ecolecon.2007.02. 024 